\title{
Zorunlu İngilizce Hazırlık Programının Değerlendirilmesi: Necmettin Erbakan Üniversitesi Yabancı Diller Yüksekokulu Örneği*
}

\section{The Evaluation of Compulsory English Preparatory Program: The Case of Necmettin Erbakan University School of Foreign Languages}

\author{
Özgül BALCI ${ }^{* *}$
}

\author{
Selma DURAK-ÜĞÜTEN ${ }^{* * *}$
}

\author{
Fatih ÇOLAK $^{* * * *}$
}

Received: 27 March 2018

Research Article

Accepted: 09 August 2018

\begin{abstract}
The English preparatory program organized by School of Foreign Languages is a yearlong English teaching program offered for students who plan to study in one of the departments at Necmettin Erbakan University. The purpose of this study was to investigate the effectiveness of compulsory English preparatory program at Necmettin Erbakan University School of Foreign Languages. A mixed-method research design was employed in which both quantitative and qualitative approaches were used. In the quantitative part of the study, the proficiency test administered at the beginning of the academic year was used as the post-test to assess the students' progress in English. A total of 70 students participated in the quantitative phase of the study. Also, semi-structured, face-to-face interviews were conducted with 20 preparatory class students in the qualitative part. The results of the quantitative data showed that students' scores improved significantly over the academic year. The results of the qualitative data analysis supported the quantitative findings. It can be concluded that English preparatory program improved students' proficiency in English though some deficiencies were noted.
\end{abstract}

Keywords: English preparatory program, evaluation of English preparatory program, compulsory preparatory program.

ÖZ: Yabancı Diller Yüksekokulu tarafından düzenlenmekte olan İngilizce hazırlık programı, Necmettin Erbakan Üniversitesi bünyesinde bulunan bölümlerden birinde öğrenim görmeyi planlayan öğrencilere yönelik bir yıl süreli bir İngilizce öğretim programdır. $\mathrm{Bu}$ çalışmanın amacı Necmettin Erbakan Üniversitesi Yabancı Diller Yüksekokulu'nda sunulan zorunlu İngilizce hazırlık programının etkililiğinin değerlendirilmesidir. Çalışma, nitel ve nicel araştırma yöntemlerinin birlikte kullanıldığı karma araştırma deseni ile yürütülmüştür. Araştırmanın nicel boyutu kapsamında akademik yılın başında yapılmış olan seviye tespit sınavı öğrencilerin İngilizce gelişimlerinin analiz edilmesi amacıyla son-test olarak kullanılmıştır. Araştırmanın nicel aşamasına toplam 70 öğrenci katılmıştır. Ayrıca nitel boyut kapsamında toplam 20 öğrenci ile yarı yapılandırılmış yüz yüze görüşmeler gerçekleştirilmiştir. Nicel verilerin analizi sonucunda öğrencilerin puanlarının akademik yıl sonunda anlamlı düzeyde arttığı görülmüştür. Nitel verilerin analizi ile elde edilen sonuçlar nicel sonuçları destekler niteliktedir. Zorunlu İngilizce hazırlık programının bazı eksikliklerin bulunmasına karşın öğrencilerin İngilizce yeterlik seviyelerini anlamlı düzeyde geliştirdiği sonucuna ulaşılabilir.

Anahtar kelimeler: İngilizce hazırlık programı, İngilizce hazırlık programının değerlendirilmesi, zorunlu hazırlık programi.

\footnotetext{
* This study was presented as an oral presentation at the Teachers Research IATEFL ReSIG Annual International Conference held in Istanbul, Turkey between 2 and 3 of June 2017.

${ }^{* *}$ Corresponding Author: Dr., Necmettin Erbakan University, Konya, Turkey, obalci@konya.edu.tr

${ }^{* * *}$ Dr., Necmettin Erbakan University, Konya, Turkey, edam2005@gmail.com

${ }^{* * * *}$ Lect., Necmettin Erbakan University, Konya, Turkey, colak_f@ hotmail.com
}

\section{Citation Information}

Balcı, Ö., Durak-Üğüten, S., \& Çolak, F. (2018). Zorunlu ingilizce hazırlık programının değerlendirilmesi: Necmettin Erbakan Üniversitesi Yabancı Diller Yüksekokulu örneği. Kuramsal Ĕgitimbilim Dergisi [Journal of Theoretical Educational Science], 11(4), 860-893. 


\section{Giriş}

İngilizcenin ülkemizde ve dünyada hayatın her alanındaki önemi herkes tarafından kabul edilen bir gerçektir ve uluslararası alandaki önemi yapılan araştırmalarda açıkça vurgulanmaktadır. British Council ve Türkiye Ekonomi Politikaları Araştırma Vakfi (TEPAV) tarafından yayımlanan araştırma raporunda ticaret, turizm ve iş dünyasındaki farklı gelişmeler nedeniyle günümüzde İngilizcenin öneminin iletişim ve etkileşimi sağlamadaki rolü gereği her geçen gün attığı ve bu durumun İngilizceyi anadili İngilizce olmayan kişiler arasında kullanılan en yaygın iletişim dili haline getirdiği açıkça ifade edilmektedir (British Council \& TEPAV, 2014). Benzer şekilde yine British Council ve TEPAV tarafından yükseköğretim kademesinde yabancı dil öğretimi konusunda gerçekleştirilen araştırma raporunda özellikle İngilizce öğretiminin her eğitim kademesinde nasıl iyileştirilebileceği konusunun güncelliğini koruduğu belirtilmektedir (British Council \& TEPAV, 2015). Türkiye'nin İngilizce konusundaki eksikliklerini konu alan çalışmalarında Koru ve Åkesson (2011), İngilizce öğrenmenin günümüz dünyasında ortak iletişim dili olması sebebiyle bir gereklilik haline geldiğini ve iş yaşamında bilgisayar becerileri ile birlikte son derece önemli rolünü vurgulamaktadırlar. Ayrıca, Kırkgöz (2007) tarafından ifade edildiği gibi Türkiye'nin stratejik ve jeopolitik konumu gereği uluslararası iletişimin sağlanması ve dünyadaki gelişmelerin takip edilebilmesi açısından ülkemizde İngilizce öğrenimi son derece önem teşkil etmektedir.

Türkiye'de yabanc1 dil eğitiminde süregelen sorunlar ve istenilen düzeyde başarının elde edilemeyişi yapılan araştırmalarda sıklıkla vurgulanan diğer bir unsurdur. Yücel, Dimici, Yıldız ve Bümen (2017) tarafından yürütülen araştırmada İngilizce eğitiminde uzun yıllardır her kademede yapılmış olan iyileştirme çalışmalarına rağmen istenen başarının halen elde edilemediği vurgulanmaktadır. British Council ve TEPAV ortaklığında yürütülen Türkiye'de devlet okullarında özellikle İngilizce eğitiminin durumu üzerine yürütülmüş olan değerlendirme çalışması sonucunda öğrencilerin bin saatten fazla sınıf içi ders görmelerine rağmen liseden mezun olurken İngilizceyi istenen düzeyde konuşup anlamada başarısız oldukları belirtilmekte ve Türkiye'de İngilizce ögretiminde başarının istenen düzeyin altında olduğu vurgulanmaktadır. Dilbilgisi odaklı ezberci yaklaşımın egemen olması, dilbilgisi odaklı değerlendirme uygulamalarının 4. sınıftan itibaren öğretim ve öğrenim sürecini yönlendirmesi, çoğu okulda mevcut iki kişilik oturma düzeninin iletişim kurmaya yönelik dil uygulamaları amacıyla verimli kullanılamaması, mevcut ders kitapları ve müfredatın öğrenci ihtiyaçlarına göre farklılık göstermemesi, teftiş sistemindeki yetersizlikler, yıllar içerisinde aynı müfredatın tekrarlaması ve öğretmenlerin müfredatı takip etme zorunluluğu gibi nedenler bu başarısızlığın başlıca nedenleri arasında gösterilmektedir (British Council \& TEPAV, 2014). Education First (EF) tarafından yürütülen araştırmada İngilizce Yeterlik Endeksi'ne (The English Proficiency Index, EPI) göre Türkiye dünyanın 16. en büyük ekonomisi olmasına ve bulunduğu bölgedeki önemine rağmen kırk dört ülke içerisinde İngilizce yeterlik düzeyi açısından kırk üçüncü sırada yer almaktadır (Koru \& Åkesson, 2011).

Yükseköğretim kademesinde de İngilizce öğretimi konusunda benzer sıkıntıların yaşandığı belirtilmektedir. British Council ve TEPAV ortaklığı ile gerçekleştirilen Türkiye'deki üniversitelerde İngilizce öğretimini konu alan araştırmanın sonucunda 
öğretimdeki eksiklikler, mevcut dağılım ve müfredatın istenen nitelikte olmadığı, öğretim elemanlarının eğitimlerindeki eksiklikler gibi problemlerin vurgulandığ görülmektedir (British Council \& TEPAV, 2015). Türkiye'de bir devlet üniversitesindeki hazırlık programının etkililiğinin değerlendirildiği Coşkun (2013) tarafından yürütülen araştırmada ise hazırlık programlarının Türkiye'de üniversite düzeyinde öğrencilere sunulan tek yoğunlaştırılmış İngilizce öğretim programı olmalarına rağmen bu programlarda da pek çok problemin yaşanıla geldiğinin altı çizilmektedir. Toker (1999) tarafından yürütülen araştırmada üniversite hazırlık programlarındaki bu problemlerden bazıları öğretim elemanlarının akademik amaçlı İngilizce öğretim tecrübesine sahip olmaması, öğretim materyalleri, haftalık ders programı ilgili sorunlar ve öğrenci sayısı olarak sıralanmaktadır. Gömleksiz (2002) tarafından yürütülen araştırmada kalabalık sınıflar, öğretim yöntem ve tekniklerinin yetersizliği, materyal eksikliği ve ders kitaplarının istenilen düzeyde olmayışı gibi nedenlerden dolayı yabancı dil eğitiminin istenilen düzeyde yürütülemediği sonucuna ulaşılmıştır.

Yükseköğretim kurumlarında yabancı dil öğretiminin amacı Yükseköğretim Kurumları Başkanlığı (YKB)'nın Yükseköğretim Kurumlarında Yabancı Dil Öğretimi ve Yabanc1 Dille Öğretim Yapılmasında Uyulacak Esaslara İlişkin Yönetmelik'i kapsamında "öğrenciye aldığı yabancı dilin temel kurallarını öğretmeyi, yabancı dil kelime haznelerini geliştirmeyi, yabancı dilde okuduğunu ve duyduğunu anlayabilmeyi ve kendisini sözlü veya yazılı olarak ifade edebilmeyi sağlamaktır" şeklinde ifade edilmektedir (YKB, 2016). Yükseköğretim kurumlarında yabancı dil öğretiminde istenilen bu amacin yerine getirilmesinde ve istenilen düzeyde İngilizce eğitiminin sağlanmasında Toker'in (1999) belirttiği gibi iyi eğitim veren hazırlık okullarının önemi ve gerekliliği muhakkaktır. Ayrıca hazırlık programları üniversite düzeyinde tek yoğunlaştırılmış İngilizce eğitimi veren programlar olması nedeniyle de önem taşımaktadır (Coşkun, 2013). Alan yazındaki çeşitli araştırmalarda vurgulandığı gibi ilköğretimden yükseköğretim kademesine kadar olan aşamalarda İngilizce eğitimi konusunda yaşanılan problemlerin devam etmesi (British Council \& TEPAV, 2014; Koru \& Åkesson, 2011; Yücel vd., 2017) göz önünde bulundurulduğunda yükseköğretim kademesine geçiş aşamasında öğrencilerin akademik ve iş yaşamlarında önem taşıyan İngilizce açıklarını kapatmaları açısından hazırlık programlarının son derece öneme sahip olduğu söylenebilir.

Alan yazında hazırlık programlarının etkililiğinin araştırıldığı pek çok araştırmaya ulaşılmıştır. Coşkun (2013) tarafından yürütülen çalışmada Türkiye'de bir üniversitede uygulanmakta olan modüler yoğunlaştırılmış genel İngilizce hazırlık öğretim program değerlendirilmiş ve modüler sistemin bazı dezavantajları sebebiyle uygulanmasının durdurulması gerektiği ve daha kullanışlı ve uygulanabilir bir sistemle değiştirilmesinin uygun olacağı sonucuna ulaşılmıştır. Arap (2016) Türkiye'deki dört devlet üniversitesinde hizmet veren İngilizce hazırlık programlarının öğrenci ve okutmanların ihtiyaçlarını ve beklentilerini kısmen karşıladığı, öğrencilerin okutmanlara kıyasla bakış açılarının daha az olumlu olduğu sonucuna ulaşmış ve bazı değişiklik ve düzenlenlemelere gerek olduğu yönünde değerlendirme yapmıştır. Gerede (2005) Anadolu Üniversitesi İngilizce hazırlık programında uygulanan eski ve yeni müfredatı öğrencilerin algıları doğrultusunda karşılaştırmış ve iki müfredat arasında konuşma, okuma ve yazma becerilerinin kazandırılmasında öğrencilerin ihtiyaçlarını karşılama 
açısından anlamlı farklar olduğu belirlenmiştir. Kırkgöz (2009) tarafindan bir devlet üniversitesinde yürütülen ihtiyaç analizi çalışmasında beceri-odaklı (skill-based) akademik amaçlı İngilizce öğretim programının öğrencilerin akademik gereksinimleri doğrultusunda yetersiz kaldığı yönünde sonuç bildirilmektedir. Mede ve Uygun (2014) tarafından İngiliz Dili ve Edebiyatı ile Mütercim Tercümanlık bölümlerine yönelik olarak hazırlanmış hazırlık programının öğrenci gereksinimlerini karşılayıp karşılamadığ 1 araştırılmış ve yürürlükteki öğretim programının dört temel dil becerisini eşit düzeyde geliştirdiği ve öğrencilerin strateji kullanımlarını olumlu yönde etkilediği sonucuna ulaşılmıştır. Özkanal ve Hakan (2010) tarafından Eskişehir Osmangazi Üniversitesi Yabancı Diller Bölümü İngilizce hazırlık programının etkililiğinin incelendiği araştırmada öğrencilerin programdan memnun oldukları, program kapsamında verilen İngilizce öğretiminin etkili olduğu ve öğretmenlerin öğretim sürecinde başarılı oldukları yanında bazı eksikliklerin de olduğu sonucuna ulaşılmıştır. Şen Ersoy ve Kürüm Yapıcıoğlu (2015), Dumlupınar Üniversitesi Yabancı Diller Bölümü İsteğe Bağlı İngilizce Hazırlık Programı'nı öğrenci ve okutman görüşleri doğrultusunda değerlendirmişler ve öğrencilerin programdan beklentilerinin de genel olarak karşılandığı sonucuna ulaşılmıştır. Toker (1999), Gaziantep Üniversitesi Yabancı Diller Bölümü öğretim elemanlarının ve birinci sınıf öğrencilerinin hazırlık programı hakkındaki görüşlerini saptamak amacıyla bir araştırma yürütmüştür. Çalışmada hem öğrenciler hem de öğretim elemanları için hazırlık eğitiminin İngilizce öğrenmek için önemli ve gerekli olması, bir yıllık hazırlık okulu süresinin yeterli olmaması, hazırlık okullarının herkesin İngilizce öğrenebileceği dil öğretim okullarına dönüştürülmesinin gerekliliği, seviye gruplarının gerekliliği, okuma becerisine daha çok önem verilmesi gerekliliği önemli sonuçlardan bazılarıdır. Tunç (2010) tarafından yürütülen araştırmada Ankara Üniversitesi Hazırlık Okulu Programı'nın etkililiği öğrenci ve okutmanların görüşleri doğrultusunda değerlendirilmiş ve programın amacına kısmen ulaştığ 1 ; bunun yanında fiziksek şartlar, içerik, kaynak ve değerlendirme unsurları açısından programın geliştirilmeye gereksinim olduğu belirtilmektedir. Örs (2006), Gaziantep Üniversitesi Yabancı Diller Yüksekokulu hazırlık öğrencileriyle yürüttüğü ihtiyaç analizi sonucunda öğrencilerin seviyeleri ve hazırlık programı hakkındaki görüşlerinde farklılıklar olduğu ve yeni bir müfredata ihtiyaç olduğu sonucuna ulaşılmıştır. Seven (2004) tarafından Atatürk Üniversitesi Fen Bilimleri Enstitüsü hazırlık sınıflarında uygulanan öğretim programının değerlendirilmesi amacıyla yürütülen araştırmanın sonucunda konuşma ve yazma derslerinin mevcut öğretim programına eklenmesi ve derslerin eşgüdüm içinde verilmesi gerektiği sonucuna ulaşılmıştır.

Yabancı dil eğitimi bütün dünyada olduğu gibi ülkemiz eğitim sisteminde son derece önem taşımaktadır. Ülkemizde yabancı dil eğitiminin iyileştirilmesi çabalarının gerek ulusal gerek kurumsal açıdan devam ettiğini söylemek yanlış olmayacaktır. Yapılan son değişikliğe göre Milli Eğitim Bakanlığı (MEB) Talim ve Terbiye Kurulu Başkanlığı (TTKB) 2013 yılı kararıyla İngilizce dersleri 2. sınıftan itibaren programda yer almaya başlamıştır (TTKB, 2013). Yabancı dil eğitim programında yapılan bu değişikliğin ülkemizde yabancı dil eğitimi süreci açısından son derece olumlu sonuçlar doğuracağı düşünülmektedir. Öyle ki British Council \& TEPAV (2014) tarafından yayımlanan araştırma raporunda yabancı dil eğitiminin 2. sınıf gibi erken bir dönemde başlatılmasının yükseköğretimi de kapsayacak şekilde bütün eğitim aşamalarında olumlu etki yaratacağı ifade edilmektedir. Ayrıca Talim ve Terbiye Kurulu; ilkokul, 
ortaokul ve liselerdeki bütün sınıf seviyelerindeki yeni öğretim programlarını Temmuz 2017'de onaylanarak kademeli bir şekilde uygulanmak üzere 2017-2018 eğitim ve öğretim yılından itibaren uygulamaya koymuştur. Yenilenen İlköğretim İngilizce Dersi (İlkokul ve Ortaokul 2, 3, 4, 5, 6, 7 ve 8. Sinıflar) Öğretim Programı (MEB, 2018a) ve Ortaöğretim İngilizce Dersi $(9,10,11$, ve 12. Sınıflar) Öğretim Programı'nın (MEB, 2018b) Avrupa Dilleri Öğretimi Ortak Çerçeve Programı'nın (ADOÇP) tanımlayıcı ve pedagojik ilkelerine göre tasarlandığı, İngilizce yeterlilik seviyeleri A1, A2 (temel kullanıcı) ile B1, B2 (Bağımsız Kullanıcı) olarak programlara yansıtıldığı, iletişimsel yetinin vurgulandığ 1 ve sınıf içi etkileşim ile derse aktif katılıma önem verildiği görülmektedir. Bu anlamda Türkiye'de yabancı dil eğitiminde iyileştirme çalışmalarının hızla ve olumlu yönde devam ettiğini söyleyebiliriz.

Necmettin Erbakan Üniversitesi Yabancı Diller Yüksekokulu, üniversite bünyesindeki tüm fakülte, yüksekokul ve meslek yüksekokullarının ortak zorunlu ve seçmeli yabancı dil derslerini ve yabancı dil (Almanca ve İngilizce) hazırlık programlarını yürütmektedir. Hazırlık programları kapsamında isteğe bağlı ve zorunlu İngilizce hazırlık programları ve zorunlu Almanca hazırlık programı sunulmaktadır. Yabanc1 Diller Yüksekokulu'nda 2012-2013 akademik y1lından itibaren hazırlık programları sunulmaktadır. Necmettin Erbakan Üniversitesi Yabanc1 Diller Yüksekokulu bünyesinde yürütülmekte olan yabancı dil hazırlık öğretiminin amacı “öğrencileri ön lisans, lisans, yüksek lisans ve doktora programlarından mezun olduklarında aldığı yabancı dilin temel kurallarını öğrenmiş, yabancı dil kelime dağarcığını geliştirmiş, yabancı dilde okuduğunu ve duyduğunu anlayabilme ve kendisini sözlü ve yazılı olarak ifade edebilme kabiliyetini kazanmış duruma getirmeyi sağlamaktır" şseklinde ifade edilmektedir (Necmettin Erbakan Üniversitesi Yabanc1 Diller Yüksekokulu Yabancı Dil Öğretimi ve Yabancı Dille Öğretim Yönetmeliği [YDÖY], 2012: madde 5). Ayrıca araştırmanın gerçekleştiği 2016-2017 akademik yılında hazırlık programları dâhilinde öğrencilere bir yıl (iki yarıyıl) süren ve haftada toplam yirmi beş ders saati dil eğitimi verilmektedir.

Necmettin Erbakan Üniversitesi Yabancı Diller Yüksekokulu bünyesinde yürütülmekte olan İngilizce hazırlık programında araştırmanın yürütüldüğü 2016-2017 akademik yılında toplam 429 öğrenciye öğretim verilmektedir. Bu öğrencilerin 318'i zorunlu hazırlık ve 111'i ise isteğe bağlı hazırlık programı öğrencileridir. Zorunlu hazırlık sınıfı ilgili yönetmelikte "öğretim dili tamamen veya kısmen yabancı dil olan programlarda öğrencinin devam etmek zorunda olduğu yabancı dil eğitimi” (YKB, 2016) şeklinde tanımlanırken isteğe bağlı hazırlık sınıfı "öğrencilerin kayıtlı olduğu, öğretim dili tamamen Türkçe olan programın ilk yarıyılından önce talepleri halinde alacağ1 yabancı dil eğitimi" (YKB, 2016) şeklinde tanımlanmaktadır. Necmettin Erbakan Üniversitesi zorunlu hazırlık programında yer alan öğrenciler uçak mühendisliği, endüstri mühendisliği, havacılık yönetimi ve uluslararası ilişkiler bölümlerine kayıtlı ve bölümlerine devam edebilmek için hazırlık sınıfını başarıyla tamamlama yükümlülüğüne sahip öğrencilerdir. İlgili yönetmeliğin 8 . Maddesinin c bendinde zorunlu hazırlık sınıfı öğrencilerinin hazırlık sınıfını başarıyla tamamlama yükümlülükleri "hazırlık sınıfını iki yıl içinde başarı ile tamamlayamayan öğrencilerin programdan ilişiği kesilir” (YKB, 2016) şeklinde ifade edilmektedir.

Öğrencilerin akademik çalışmaları ve iş yaşamları açısından İngilizcenin etkili bir şekilde kullanımı muhakkaktır. Bunun yanında zorunlu hazırlık programı 
öğrencilerinin kayıtlı oldukları bölümlerin en az \%30 oranında İngilizce olması sebebiyle hazırlık programını başarıyla tamamlayamayan öğrencilerin bölümlerinin birinci sınıflarına devam etmeleri mümkün olmamaktadır. $\mathrm{Bu}$ nedenler göz önüne alındığında zorunlu İngilizce hazırlık sınıfı öğrencileri açısından İngilizce yeterliklerinin istenen düzeye ulaşması son derece önemlidir. Bu araştırmada Necmettin Erbakan Üniversitesi Yabancı Diller Yüksekokulu tarafından sunulmakta olan zorunlu İngilizce hazırlık programının etkililiğinin araştırılması hedeflenmektedir. Alan yazında Necmettin Erbakan Üniversitesi bünyesindeki fakültelerin farklı bölümlerine kayıtlı olan çok sayıda öğrenciye hizmet sunan zorunlu İngilizce hazırlık programının etkililiğinin değerlendirildiği başka bir araştırmaya ulaşılamamıştır. Ayrıca farklı üniversitelerdeki hazırlık eğitiminin etkililiğinin değerlendirildiği diğer araştırmaların (Arap, 2016; Coşkun, 2013; Gerede, 2005; Özkanal \& Hakan, 2010; Toker, 1999) genelde öğrenci ve öğretim elemanı görüşleri doğrultusunda yürütüldüğü görülmektedir. $\mathrm{Bu}$ araştırma, öğrenci görüşleri yanında bir yıllık hazırlık programının öğrencilerin başarılarına odaklanılarak değerlendirilmeye çalışılması açısından diğer araştırmalardan farklılık göstermektedir. İngilizcenin öğrencilerin akademik çalışmaları ve iş yaşamlarındaki önemi ile zorunlu hazırlık program öğrencilerinin bölümlerine devam edebilmeleri için programı başarıyla tamamlamarının gereği düşünüldüğünde zorunlu İngilizce hazırlık programının etkililiğinin değerlendirilmesinin son derece önemli olduğu düşünülmektedir. Ayrıca zorunlu hazırlık programının değerlendirilmesinde nicel verilerin yanında öğrenci görüşlerine başvurularak nitel verilerin de kullanılmasının çok yönlü bir değerlendirmenin yapılabilmesi açısından önem taşıdığı düşünülmektedir. Araştırma sonuçlarının Türkiye'de yükseköğretim kurumlarında yabancı dil hazırlık eğitimi konusunda yaşanmakta olan sorunların çözümünde kullanılabilecek yeni fikirler sunacağı; bunun yanında yükseköğretim yabancı dil alanında program geliştirme çalışmalarına, öğrenme-öğretme uygulamalarına ve Türkiye'de yabancı dil eğitimi ile ilgili alan yazın çalışmalarına katkı sağlayacağı umulmaktadır. Yukarıda belirtilen hususlar, alan yazın ve araştırmanın genel amacı kapsamında bir hipotez ve bir araştırma sorusu oluşturulmuştur:

"Yürütülen bir yıllık zorunlu İngilizce hazırlık programı öğrencilerin İngilizce dinlediğini anlama, okuduğunu anlama ve dilin kullanımı ile ilgili yeterlik düzeylerini geliştirmektedir."

"Öğrencilerin İngilizce zorunlu hazırlık programının İngilizce başarıları açısından etkililiği ile ilgili algıları nasıldır?”

\section{Yöntem}

\section{Araştırma Deseni}

Çalışma, nitel ve nicel araştırma yöntemlerinin birlikte kullanıldı̆̆ araştırma deseni ile yürütülmüştür. Karma araştırma yöntemi, daha çok ve farklı çeşitte verinin toplanması ile analiz edilmesini mümkün kılması açısından araştırmacılara fayda sağlamaktadır (Fraenkel, Wallen, \& Hyun, 2012, s. 11). Araştırmanın nicel boyutu kapsamında 2016-2017 akademik yılı başında yapılmış olan yeterlik sınavı öğrencilerin yıl süresince İngilizce gelişimlerinin analiz edilmesi amacıyla son-test olarak kullanılmıştır. Araştırmanın nitel boyutunda ise, gönüllü öğrenciler ile yarı yapılandırılmış yüz yüze görüşmeler gerçekleştirilmiştir. Bu araştırmada karma araştırma yöntemlerinden açıklayıcı karma yöntem kullanılmıştır. Fraenkel vd.'e (2012, 
s. 560) göre açıklayıcı karma yöntemde önce nicel yöntem ile araştırma yapıldıktan sonra nitel yöntem kullanılarak sonuçların derinlemesine araştırılması amaçlanır. Elde edilen nicel ve nitel veriler ayrı ayrı analiz edilmektedir. Nitel verilerin analiziyle elde edilen sonuçlar, nicel verilerin analiziyle elde edilen sonuçların ayrıntılı hale getirilmesi ve derinlemesine açıklanması amacıyla kullanılmaktadır. $\mathrm{Bu}$ araştırmada zorunlu İngilizce hazırlık programının etkililiğinin değerlendirilmesi amacıyla öncelikle nicel veriler toplanarak analiz edilmiş, ardından nitel veriler toplanarak içerik analizine tabi tutulmuş ve böylece sonuçlar derinlemesine araştırılmaya çalışılmıştır.

\section{Çalışma Grubu}

Araştırmanın nicel boyutuna 2016-2017 akademik yılı başında Yüksekokul tarafından yapılmış olan yeterlik sınavına katılmış olan toplam 70 (40 erkek ve 30 kadın) öğrenci katılmıştır. 2016-2017 akademik yılında zorunlu İngilizce hazırlık sınıflarında öğrenim görmekte olan öğrenci sayısı 318 olmasına karşın toplam 137 öğrenci sene başı yeterlik sınavına katılmıştır. Sene başı yeterlik sınavına katılan 137 öğrencinin 24'ü önceki yıllarda hazırlık sınıfından başarısız olup bölümlerine devam etmekte olan ve araştırma kapsamı dışındaki öğrencilerdir. Sene başı yeterlik sınavına katılan 137 öğrenciden 113’ü o yıl üniversiteyi kazanan ve zorunlu İngilizce hazırlık sınıfına devam etmesi gereken öğrencilerdir. 113 zorunlu İngilizce hazırlık sınıfı öğrencisinin 17'si yeterlik sınavında başarılı olmuş ve hazırlık sınıfını atlayıp bölümlerine geçmişlerdir. Geriye kalan 96 öğrenci 2016-2017 akademik yılı başında zorunlu İngilizce hazırlık sınıfına başlamıştır. Bu öğrencilerin 33'ü uluslararası ilişkiler, 17'si uçak mühendisliği, 36's1 havacılık yönetimi ve 10'u endüstri mühendisliği bölümlerine kayıtlı öğrencilerdir. Araştırma kapsamındaki bu 96 öğrenci içerisinden araştırmaya gönüllü olarak katılmak isteyen toplam 70 öğrenci araştırma kapsamına alınmıştır. Öğrencilerin araştırmaya katılımında gönüllülük esas alınmıştır. Sene başı seviye tespit sınavına katılmış olan öğrenciler belirlendikten sonra kendileriyle iletişime geçilerek araştırmanın amacı ve içeriği hakkında bilgi verilmiş ve katılımın tamamen gönüllülük esasına dayandığı, sonuçların hiçbir şekilde hazırlık sınıfı başarı puanlarını etkilemeyeceği açıklanmıştır. Ön-test ve son-test farkının değerlendirilebilmesi amacıyla sene başı seviye tespit sınavına katılan 96 öğrenciden 70 öğrencinin gönüllü olması nicel araştırma kapsamına alınan öğrenci sayısının 70 ile sınırlandırılmasını gerektirmiştir. Araştırmanın nitel boyutunda ise nicel araştırma aşamasına katılmış olan öğrenciler içerisinden araştırmanın nitel boyutuna gönüllü olarak katılmak isteyen toplam 20 ögrenci (10 erkek ve 10 kadın) ile yarı yapılandırılmış görüşmeler gerçekleştirilmiştir.

\section{Veri Toplama Araçları}

Hazırlık eğitiminin öğrencilerin İngilizce yeterlik düzeylerine etkisinin belirlenebilmesi ve araştırmanın nicel verilerinin toplanması amacıyla sene başında Yabancı Diller Yüksekokulu tarafından yapılmış olan yeterlik sınavı ön-test olarak kabul edilmiş ve aynı sınav akademik yıl sonunda öğrencilere son-test olarak uygulanmıştır. Seviye tespit sınavı Yabancı Diller Yüksekokulu müdürlüğünce kurulmuş olan sınav komisyonu tarafından hazırlanmaktadır. Sınav kapsamında dinleme, okuma, dil kullanımı, kelime dağarcı̆̆ı ve yazma becerilerini ölçen sorular bulunmaktadır. Yazma bölümü dışında bütün sorular çoktan seçmeli test maddelerinden 
oluşmakta ve objektif bir şekilde değerlendirilmektedir. Yazma bölümü ise müdürlük tarafından görevlendirilen öğretim elemanları tarafından sınav komisyonunun hazırlamış olduğu değerlendirme rubriği kullanılarak puanlandırılmaktadır. Bu araştırma kapsamında son-test olarak uygulanan yeterlik sınavında bir nebze de olsa öznel görüş içerebileceği, araştırmanın geçerlik ve güvenirliğini etkileyebileceği düşüncesiyle yazma bölümü sınava dâhil edilmemiş ve değerlendirme yazma bölümü dikkate alınmadan yapılmıştır. Aynı şekilde sene başında yapılmış olan yeterlik sınav sonuçları yazma bölümü puanları dâhil edilmeden hesaplanarak araştırma kapsamında ön-test puanları olarak kullanılmıştır. Yeterlik sınavının orijinal şeklinden alınabilecek minimum puan 0 ve maksimum puan 100 iken bu araştırma kapsamında yazma bölümü ön-test ve son-test için değerlendirilmeye alınmadığından testten alınacak minimum puan 0 ve maksimum puan 80 olarak belirlenmiştir. Araştırmada kullanılan soru türleri ve sayıları Tablo 1'de verilmiştir:

Tablo 1

Yeterlik Sinavı Soru Türleri Ve Sayıları

\begin{tabular}{ll}
\hline Ölçülen Beceriler & Soru Türleri ve Sayıları \\
\hline Dinlediğini Anlama & Ana fikir için dinleme (5 soru) \\
& Ayrıntılar için dinleme (5 soru) \\
Okuduğunu Anlama & Diyalog tamamlama (5 soru) \\
& Cümle tamamlama (5 soru) \\
& Anlam bütünlüğünü bozan cümleyi bulma (5 soru) \\
& Okuduğu metni anlama (10 soru) \\
Dilin Kullanımı & Paragraf içi boşluk doldurma (15 soru) \\
& Cümle içi boşluk doldurma (10 soru) \\
\hline
\end{tabular}

Araştırmanın nitel boyutu kapsamında ise, öğrencilerin İngilizce zorunlu hazırlık programının etkililiği ile ilgili algılarının incelenmesi ve nicel verilerin ayrıntılı hale getirilerek derinlemesine açıklanabilmesi amacıyla araştırma sorusu ve ilgili alan yazın dikkate alınarak yarı yapılandırılmış görüşme formu araştırmacılar tarafından hazırlanarak kullanılmıştır. Görüşme formunda öğrencilerin zorunlu İngilizce hazırlık programına katılma amacı ve beklentileri, programın etkililiği, hazırlık programının İngilizce okuma, yazma, dinleme ve konuşma becerilerine katkısı ve hazırlık programı ile ilgili eleştiri ve öneriler ile ilgili konuları ele alan toplam yedi açık uçlu soru yer almaktadır. Görüşme formunun hazırlanmasında Yıldırım ve Şimşek (2008, ss. 128138) tarafından belirtilen görüşme sorularının hazırlanmasında dikkat edilecek husular dikkate alınmıştır. Hazırlanan görüşme formu uzman görüşüne sunulmuştur. Uzman görüşleri doğrultusunda soru sayısında azaltma yoluna gidilmiş ve bazı soruların ifade şekilleri değiştirilmiştir. Sonrasında soruların öğrenciler tarafından doğru anlaşılıp anlaşılmadığı, araştırma amacına uygunluğu ve olası problemleri tespit edebilmek amaciyla ön denemeye tabi tutulmuş ve 3 öğrenciyle ön deneme görüşmeleri yapılmıştır. $\mathrm{Bu}$ görüşmeler sırasında herhangi bir sorun yaşanmadığı görülmüş ve görüşme formunun bu şekliyle kullanılmasının uygun olacağı kanısına varılmıştır. 


\section{Verilerin Toplanması}

Nitel ve nicel veriler, 2016-2017 akademik yılı bahar döneminde araştırmacılar tarafından toplanmıştır. Öğrencilere araştırma ile ilgili bilgi verilmiş ve katılımın gönüllülük esasına dayandığı belirtilmiştir. Nicel verilerin toplanması amacıyla öğrenciler ile önceden görüşülerek zaman ayarlaması yapılmıştır. Araştırmaya katılan ögrenciler farklı sınıflarda öğrenim gördüklerinden dolayı yeterlik sınavının son-test olarak uygulanması öğrencilerin ders dışında uygun oldukları zamanlar göz önünde bulundurularak öğrencilerin iki gruba ayrılması suretiyle farklı zamanlarda gerçekleştirilmiştir. Nicel veriler 16-20 Mayıs 2016 tarihleri arasında toplanmıştır.

Nitel verilerin toplanması nicel verilerin toplanarak analiz edilmesinden sonraki hafta olan 23-27 Mayıs 2016 tarihleri arasında gerçekleştirilmiştir. Nitel verilerin toplanması amacıyla görüşmeler öğrenciler ile önceden ayarlanmış olan saatte, iki araştırmac1 ve görüşme yapılacak öğrencinin katılımıyla gerçekleştirilmiştir. Öğrencilerden izin alınarak görüşmeler ses kayıt cihazı ile kayıt altına alınmıştır. Görüşme sürecinde soruların konuşma tarzında sorulmasına dikkat edilmiş ve yönlendirme yapmadan sürecin kontrol edilmesini sağlamak amaciyla görüşmelerde en az iki araştırmacının bulunması sağlanmıştır. Yapılan görüşmelerin süresi 10 ile 18 dakika arasında değişmektedir.

\section{Verilerin Analizi}

Nicel verilerin normal dağılıma uygunluğu Kolmogorov-Smirnov testi kullanılarak ve varyansların homojenliği Levene testi kullanılarak analiz edilmiştir. Yeterlik sınavı sonucunda öğrencilerin ön-test ve son-test puan ortalamaları arasındaki fark, SPSS 16.0 programı kullanılarak bağımlı gruplarda t testi ile analiz edilmiştir. İstatistiksel anlamlılık düzeyi $p<0.05$ olarak kabul edilmiştir.

Nitel veriler ise "kodlama, temaların bulunması, kod ve temaların düzenlenmesi ile bulguların tanımlanarak yorumlanması" olarak ifade edilen dört aşamadan oluşan içerik analizi (Yıldırım \& Şimşek, 2008, s. 228) kullanılarak çözümlenmiştir. İçerik analizi araştırmacıların insan davranışını dolaylı yoldan, bireylerin kurdukları iletişimlerin analizi yoluyla incelemesine olanak sağlayan bir tekniktir (Fraenkel vd., 2012, s. 478). Bu araştırmada içerik analizi sürecinde öncelikle ses kayıtları yazıya dökülerek bilgisayar ortamına aktarılmıştır. Ses kayıtları tekrar dinlenilerek araştırmacılar tarafından yazıya dökülmüş metinler ile tekrar karşılaştırılmıştır. Verilerin kodlanmasında "genel bir çerçeve içinde yapılan kodlama" (Yıldırım \& Şimşek, 2008, s. 232) biçimi kullanılmıştır. Veriler, araştırmacılar tarafından birçok kez satır satır okunduktan sonra araştırmanın amacı dikkate alınarak öğrencilerin her soruya verdiği cevaplar ayrı ayrı incelenerek kodlama yapılmıştır. Kodlama araştırma sorusu ve ilgili alan yazın dikkate alınarak önceden oluşturulan genel temalar dikkate alınarak yapılmıştır. Veri analizi sürecinde ortaya çıkmış olan kodlar listelenerek benzerlik ve farklılıkları incelenmiştir. Buna göre katılımcıların sorulara verdikleri yanıtlarda benzer şekilde kodlanan kısımlar belli kategoriler altında bir araya getirilerek oluşturulmuş olan temalar altında birleştirilmiştir. Sonrasında veriler, elde edilen kod ve temalara göre düzenlenip frekans ve yüzdeleri bulunarak tablolar şeklinde sunulmuştur. Son olarak, elde edilen bulgular araştırmacılar tarafından yorumlanarak sonuçlar çıkarılmış ve raporlaştırılmıştır. 


\section{Geçerlik ve Güvenirlik}

Araştırmanın nicel aşamasında Yüksek Okul tarafından sene başında uygulanmış olan yeterlik sınavı kullanılmıştır. Sınav Yüksek Okul Sınav Komisyonu tarafından titizlikle hazırlanmış olmasına karşın geçerlik ve güvenirlik çalışmaları yapılmamıştır. $\mathrm{Bu}$ durum araştırmanın bir sınırlılı̆̆ı olarak 'Araştırmanın Sınırlılıkları' bölümünde ayrıntılı bir şekilde ifade edilmektedir.

Araştırmanın nitel boyutu kapsamında geçerlik ve güvenirliğin sağlanabilmesi amacıyla Yıldırım ve Şimşek (2008, s. 265) tarafından belirtildiği üzere bazı stratejilerden faydalanılmıştır. İnandırıcılığın (iç geçerlik) sağlanabilmesi amacıyla yapılan görüşmelerin süreleri mümkün olduğunca uzun tutulmaya çalışılmış, araştırma sürecinin her aşamasında uzman görüşüne başvurulmuştur. Ayrıca, elde edilen sonuçlar sürekli olarak karşılaştırılarak yorumlanmış ve verilerin araştırma sorusuna yönelik yeterliği araştırmacılar tarafından sürekli denetlenmiş, böylece derinlemesine veri toplama yoluna gidilmiştir. Bunun yanında, yapılan her görüşme sonunda toplanan veriler araştırmacılar tarafından özetlenerek katılımcıdan elde edilen verilerin doğruluğunu teyit etmesi istenmiştir. Aktarılabilirliğin (dış geçerlik) sağlanması amacıyla verilerin raporlanması aşamasında doğrudan alıntılara sıkça yer verilmiş ve araştırma süreci mümkün olduğunca ayrıntılı bir şekilde açıklanmıştır. Tutarlığın (iç güvenirlik) sağlanması amacıyla araştırma süreci kapsamında gerçekleştirilmiş bütün iş ve işlemler sırasında uzman görüşüne başvurulmuştur. Görüşmeler en az iki araştırmacı tarafından gerçekleştirilmiş, böylece görüşmelerin aynı standartta gerçekleştirilmesi denetlenmeye çalışılmıştır. Verilerin kodlanması aşamasında oluşmuş kodların güvenirliğinin sağlanması amaciyla kod ve temaların uygunluğu konusunda nitel araştırma konusunda uzman bir öğretim üyesinin görüşlerine başvurulmuştur. Ayrıca veri analizinin iki araştırmacı tarafından yürütülmesi nedeniyle kodlama güvenirliğini belirlemek amacıyla kodlama yüzdesi belirlenerek aradaki tutarlılık incelenmiştir. Buna göre kodlayıcılar arası tutarlılık "Güvenirlik = Görüş birliği / (Görüş Birliği + Görüş Ayrılığı) x 100” (Miles ve Huberman, 1994) formülü kullanılarak hesaplanmıştır. Kodlayıcılar arası güvenirlik \%88.5 olarak hesaplanmıştır. Yıldırım ve Şimşek (2008, s. 233), veri analizinin birden fazla araştırmacı tarafından yapıldığı durumlarda en az \%70 düzeyinde bir güvenirlik yüzdesine ulaşılması gerektiğini belirtmektedirler. Bu nedenle çalışmada, kodlama güvenirliğinin yeterli olduğu söylenebilir. Teyit edilebilirliğin (dış güvenirlik) sağlanması amacıyla da yine elde edilen sonuçlar ile ham verilerin karşılaştırılarak teyit edilmesini sağlamak için uzman görüşü alınmıştır.

\section{Varsayım ve Sinırlılıklar}

$\mathrm{Bu}$ araştırma kapsamında elde edilen sonuçların yorumlanmasında göz önünde bulundurulması gereken bazı sinırlılıklar bulunmaktadır. Öncelikle resmi yazılı bir öğretim programının bulunmaması nedeniyle programın öğeleri açısından değerlendirilmesinin mümkün olmaması bir sınırlılık olarak düşünülmektedir. Necmettin Erbakan Üniversitesi Yabancı Diller Yüksekokulu tarafindan uygulanan resmi bir öğretim programının olmaması nedeniyle bu araştırmada öğretim programının farklı unsurları göz önünde bulundurularak değerlendirilmesi yoluna gidilememiş, bunun yerine verilen bir y1llık öğretimin nicel ve nitel veriler kullanılarak öğrencilerin İngilizce başarısı üzerindeki etkisinin incelenmesi yoluyla hazırlık programının etkililiği değerlendirilmeye çalışılmıştır. Bunun yanında araştırmanın katılımcı sayısı nicel boyut 
kapsamında 70 ve nitel boyut kapsamında 20 öğrenci ile sınırlıdır. Nitel boyut kapsamında araştırmaya katılan öğrenci sayısı nispeten yeterli görülse de araştırmaya katılmaya gönüllü olan sadece 70 zorunlu hazırlık öğrencisinin sene başında yapılmış olan seviye tespit sınavına katılmış olması nedeniyle nicel boyut kapsamındaki öğrenci sayısı aynı testin son-test olarak kullanılmasından ötürü bu sayıyla sınırlandırılmak zorunda kalmıştır. Bu nedenle, araştırmada elde edilen bulguların sınırlı bir öğrenci grubundan elde edildiği göz önünde bulundurularak sonuçların aşırı genellemesinden kaçınılmalıdır. Diğer bir sınırlılık ise sınav komisyonu tarafından hazırlanarak sene başında yapılmış olan yeterlik sınavının bu araştırmada kullanılmasıdır. $\mathrm{Bu}$ testin geçerlik ve güvenirlik çalışması yapılmamıştır. Bu nedenle araştırmacılar bu sınırlılığın ortadan kaldırılması amacıyla bundan sonra yapılacak araştırmalarda geçerlik ve güvenirliği yapılmış standart bir testin kullanılmasını tavsiye etmektedirler. Ayrıca araştırmanın nitel boyutu kapsamında öğrencilerin kendilerine yöneltilen soruları dürüstçe yanıtladıkları ve bu yanıtların var olan durumu doğru bir şekilde yansıttığ varsayılmıştır.

\section{Bulgular}

\section{Araştırma Hipotezine Yönelik Bulgular}

Araştırma hipotezinin test edilmesi amacıyla sene başında uygulanmış olan yeterlik sınavı son test olarak tekrar uygulanmış ve sonuçlar bağımlı gruplarda t testi ile analiz edilmiştir. T testi sonuçları aşağıda Tablo 2'de verilmiştir:

Tablo 2

Ön Test ve Son Test Yeterlik Sinavı Sonuçları

\begin{tabular}{lcccccc}
\hline & $\boldsymbol{n}$ & Min & Maks & $\overline{\mathrm{X}}$ & $\boldsymbol{s}$ & $\boldsymbol{t}$ \\
\hline Ön test & 70 & 5 & 53 & 32.3 & 10.04 & $-14.75^{*}$ \\
Son test & 70 & 22 & 69 & 47.8 & 11.28 & \\
\hline
\end{tabular}

${ }^{*} p<0.05$; Ön-test ve son-test puan ortalamaları arasında istatistiksel olarak anlamlı farklılık. $\overline{\mathrm{X}}$ : Aritmetik ortalama, ss: Standart sapma

Tablo 2'de görüldügü gibi yeterlik sınavı ön test ve son test puan ortalamaları arasında anlamlı fark bulunmuştur. Buna göre zorunlu hazırlık programının öğrencilerin İngilizce dinlediğini anlama, okuduğunu anlama ve dilin kullanımı ile ilgili yeterlik seviyelerini anlamlı düzeyde geliştirdiği söylenebilir.

\section{Araştırma Sorusuna Yönelik Bulgular}

Araştırma sorusu ve ilgili alan yazın dikkate alınarak genel temalar önceden belirlenerek genel bir çerçeve oluşturulmuştur. Görüşmeler ile elde edilen verilerin analizi sonucunda tema ve alt temalara son şekli verilmiştir. Görüşme yapılan öğrenciler sırasıyla Ö1 (Öğrenci 1), Ö2 (Öğrenci 2) şeklinde kodlanmıştır. Bu bölümde bulgular tema ve alt temalar altında doğrudan alıntılar yoluyla sunulmuştur. Belirlenen ana tema ve alt temalar aşağıdaki gibidir: I. Hazırlık programına katılma amacı ve beklentiler, II. Programın etkililiği ve memnuniyet, III. Hazırlık programının dil yeterlik düzeyine etkisi (Yazma, dinleme, okuma, konuşma ve diğer dil becerilerine etkisi), IV. Hazırlık 
programı ile ilgili eleştiri ve öneriler (Dersler, öğretim elemanları, değerlendirme ve diğer).

\section{Hazırlık programına katılma amacı ve beklentiler}

Öğrencilerin hazırlık programına katılma amaçları ve beklentilerinin belirlenebilmesi amacıyla görüşme formunda öğrencilere yöneltilen soru "Hazırlık programına katılma amacınız ve programdan beklentileriniz nelerdir?" şeklinde ifade edilmiştir. Öğrencilerin zorunlu hazırlık programına katılma amacı ve beklentileri ile ilgili bulgular ile bulgulara ilişkin frekans dağılımları ve yüzde değerleri Tablo 3'de verilmiştir.

Tablo 3

Hazırlık Programına Katılma Amacı ve Programdan Beklentiler

\begin{tabular}{llll}
\hline $\begin{array}{l}\text { Hazırlık programına katılma amacı ve } \\
\text { programdan beklentiler }\end{array}$ & $f$ & $\%$ & \multicolumn{1}{c}{ Katılımcılar } \\
\hline İngilizceyi iyi seviyede öğrenmek & 16 & 80 & $1-2-3-5-6-7-8-9-10-11-12-13-15-17-19-20$ \\
Öğrenim görülen bölümün gerekliliği & 9 & 45 & $1-4-6-8-9-15-16-17-18$ \\
Akıcı konuşma becerisi kazanmak & 7 & 35 & $1-2-9-11-15-16-18$ \\
Dil bilgisi seviyesini geliştirmek & 1 & 5 & 1 \\
Bir sene dinlenme yılı olarak geçirmek & 1 & 5 & 13 \\
\hline
\end{tabular}

Tablo 3 incelendiğinde öğrencilerin çoğunun (\%80) zorunlu İngilizce hazırlık programına katılma amaçlarını İngilizceyi iyi seviyede öğrenmek olarak ifade ettikleri belirlenmiştir. Öğrencilerin yarısına yakını (\%45) hazırlık programına öğrenim gördükleri bölümün bir gereği olması nedeniyle katıldıklarını belirtmektedirler. Ayrıca bölümlerinin bir gereği olması nedeniyle hazırlık programına katıldıklarını belirten öğrencilerden bazıları (\%30) (Öğrenci 1, 6, 8, 9, 15, 17) aynı zamanda İngilizceyi iyi bir şekilde öğrenmek amacıyla da bu programa başvurduklarını belirtmektedirler. Yine öğrencilerin bazıları (\%35) hazırlık programına katılma amaçlarının İngilizce akıcı konuşma becerisi kazanmak olduğunu beyan etmektedirler. Akıcı konuşma becerisi kazanmak amacıyla hazırlık programına katıldıklarını ifade eden öğrencilerin bazıları (\%25) (Öğrenci 1, 2, 9, 11, 15) da aynı zamanda İngilizceyi iyi bir şekilde öğrenmek amacıyla da bu programa başvurduklarını belirtmektedirler. Bunların dışında sadece bir öğrenci (\%5) hazırlık programına katılma amacının dil bilgisi seviyesini geliştirmek olduğunu ve sadece bir öğrenci (\%5) hazırlık programına bir sene dinlenme yılı olması amacıyla katıldığını ifade etmektedir. Aşağıda hazırlık programına katılma amacı ile ilgili öğrenci görüşlerinden doğrudan alıntılara yer verilmiştir:

Ö1. "Havacılık Yönetimi okuyorum bu yüzden İngilizceyi ögrenmem gerekiyor, yani İngilizceyi öğrenmek için geliyorum daha çok, geçmek için değil de. Muafiyete girdim geçemedim, ama faydasi oldu mu derseniz, bence oldu. Beklentilerim, Ingilizce konuşmamı birazcık daha akıcı bir hale getirmek ve işte yeni grammerler (dilbilgisi) öğrenip normal yaşamda daha kolay olmasıydı yani." 
Ö3. "Yani Ingilizcemi daha iyi geliştirmek istiyordum. Az çok bir şey biliyordum. İlerdeki hayalim yurtdışında çalışmak, Türkiye'de değil. İngilizceyi tamamen bitirip üstüne bir dil daha koymayı düşünüyordum. Ondan geldim.”

Ö7. "Ingilizcemi daha iyi geliştirmek için ben daha önceden ortaokuldan beri Ingilizce görmüyorum. Yani İngilizcemi geliştirip daha iyi yerlere getirmek için. Ya ikinci dil olarak Ingilizcemi daha iyi geliştirmek istiyorum."

Ö8. "Bizim ilkokuldayken İngilizcemiz hocalarımı falan işte beden ĕgitimi hocasi Ingilizce dersine giriyordu. Temelimiz yoktu buraya temel atmaya geldik. Zaten bölümümüz de bunu gerektiriyor. En az iki dil gerektiriyor. Ingilizceyi hazırlık sınıfina temel atmak için geldim diyebilirim."

Ö9. "Bölümüm yüzde yüz Ingilizce. Benim için Ingilizce çok önemli bu yüzden de muafiyet sınavını geçemedim. Bu yüzden de Ingilizce hazırlık sinıfina geldim. Yani amacım tabi ki de İnilizceyi ögrenmek. Çok üstün beklentilerim yoktu ama Ingilizceyi ögrenmek gibi bir beklentim vardl."

Ö17. "Katılma amacım, bir kere bölümüm için zorunluydu. Ingilizcem yeterli geliyordu aslında ama muafiyetten geçemeyince... 3 puanla falan şey olmuştu. Öyle işte ondan sonra, işte yani İngilizcemi yeterince geliştirmeye çalışmak, olduğu kadar."

Ö18. "Bir kere ilk başta Speaking'in (konuşma becerisi) gelişmesini istiyordum ve ilerde yurt dişına gittiğimde rahatça konuşup anlayabilmek istiyordum. İkincisi benim bölümümde makale yazmam gerekiyor, yani bu yüzden Ingilizcemi geliştirmem lazımdl."

\section{Programın etkililiği ve programdan memnuniyet}

Zorunlu hazırlık programının etkililiği ve öğrencilerin programdan memnuniyetinin belirlenebilmesi amacıyla görüşme formunda öğrencilere "Hazırlık programının etkililiği konusunda düşüncelerin nelerdir?” sorusu yöneltilmiştir. Bulgulara ilişkin frekans dağılımları ve yüzde değerleri Tablo 4'de verilmiştir.

Tablo 4

Zorunlu Hazırlık Programının Etkililiği ve Programdan Memnuniyet

\begin{tabular}{lccc}
\hline Zorunlu hazırlık programının etkililiği & $\boldsymbol{f}$ & $\%$ & \multicolumn{1}{c}{ Katılımcılar } \\
\hline Son derece etkili & 13 & 65 & $1-2-4-5-6-7-8-9-12-15-17-19-20$ \\
Kısmen etkili & 6 & 30 & $3-11-13-14-16-18$ \\
Hazırlığın hiçbir etkisi yok & 1 & 5 & 10
\end{tabular}

Zorunlu hazırlık programının etkililiği ile ilgili görüşler incelendiğinde öğrencilerin çoğunun (\%65) programın son derece etkili olduğu ve programdan son derece memnun oldukları yönünde görüş bildirdikleri tespit edilmiştir. Öğrencilerin bazıları ise (\%30) zorunlu hazırlık programını kısmen etkili olarak nitelemişler ve programdan kısmen memnun olduklarını belirtmişlerdir. Bunun yanında sadece bir öğrencinin (\%5) programın İngilizce seviyesi üzerinde hiçbir etkisinin olmadığı ve 
zorunlu hazırlık programından memnun olmadığı görüşünde olduğu görülmektedir. Hazırlık programının etkililiği ile ilgili öğrenci görüşlerinden bazıları aşağıdaki gibidir:

Ö4. "Evet, faydallydı hocam kendim yani kendime göre söyleyeyim. Benim için her zaman spikingler (konuşma etkinlikleri) faydalı olmuştur. Hani çünkü ne biliyim. Bakarak ögrenmekten çok ben konuşarak öğreniyorum işte bir şekilde etkinliklerin içinde daha çok faydalı olduğunu düşünüyorum. Çok memnunum, problem yok."

Ö5. "Ne düşünüyorum. Bence gayet etkili yani hocalarımız çok iyi. Ama biraz biz salliyoruz yani. Ben çok etkili buluyorum faydalı buluyorum gerçekten."

Ö6. "Benim için mi? Benim için kesinlikle faydalıydl. Yani burada belli bir kur yoktu. Herkes aynı şeyde (seviyede) başladı ve basit düzeyden başladiğı için benim işime geldi açıkçası. Bilen arkadaşlar da aynı başladı onlar için kötü ama ben bilmediğim için iyi oldu baştan başladık. Evet, ben çok faydalı buldum."

Ö9. "Tabi ki çok faydası oldu. Onu görmezden gelemem çok fazla ilerleme kaydettim Ingilizce de. Ama hani ben konuşma adına anlama adına daha fazla şey yapmak isterdim. Daha iyi bir noktaya gelmek isterdim. Şu an bununla ilgili isteğim hala var. Yazın onları da tamamlamayı düşünüyorum.”

Ö10. "Illk dönem iyi güzeldi yine çaba gösteriyordum hocam. İkinci dönem koptu bende sıfır. Hiçbir etkisi yok bence hazırlı̆̆ın. Gereksiz. Evet, okuldan kaynaklaniyor bence."

Ö11. "Ya açıkçası bence faydalı ama yeteri kadar mı bilmiyorum. İleride bölüm hakkında ya da bölümde materyal hakkında herhangi bir bilgi ya da bizim açımızdan bir şey verilmediği için yani ileriye yansır mı bilmiyorum."

Ö18. "Yani birazcık karşılandı denilebilir. Bu sene yabancı öğretmenimiz yoktu, biraz o sıkıntılıydı, o kadar."

\section{Hazırlık programının dil yeterlik düzeyine etkisi}

Zorunlu hazırlık programının İngilizce yeterlik düzeyine etkisinin belirlenebilmesi amacıyla görüşme formunda öğrencilere hazırlık programının dört temel dil becerisine etkisi konusunda toplam dört soru yöneltilmiştir. Her soru farklı dil becerisi yönelik olarak sorulmuştur: "Hazırlık programının İngilizce yazma (dinleme, okuma, konuşma) becerisine etkisi konusunda düşüncelerin nelerdir?”

Öğrencilerin zorunlu hazırlık programının dört temel dil becerisine etkisi ile ilgili bulgulara ilişkin frekans dağılımları ve yüzde değerleri Tablo 5'de verilmiştir. 
Tablo 5

Hazırlık Programının Dil Yeterlik Düzeyine Etkisi

Hazırlık programının dil yeterlik düzeyine etkisi

f $\% \quad$ Katılımcilar

a. Yazma becerisine etkisi

Yazma becerimi son derece geliştirdi

1-2-3-4-6-7-8-9-10-12-13-14-15-16-17-

$18-19-20$

Yazma becerimi kısmen geliştirdi

Yazma becerimi geliştirmedi

$\begin{array}{lll}1 & 5 & 11 \\ 1 & 5 & 5\end{array}$

b. Dinleme becerisine etkisi

Dinleme becerimi son derece geliştirdi

$5 \quad 25$

4-15-16-17-20

Dinleme becerimi kısmen geliştirdi

$9 \quad 45$

$1-5-6-7-9-10-12-13-18$

Dinleme becerimi geliştirmedi

$6 \quad 30$

2-3-8-11-14-19

c. Okuma becerisine etkisi

Okuma becerimi son derece geliştirdi

$13 \quad 65$

$1-3-5-7-8-11-12-13-15-16-17-18-20$

Okuma becerimi kısmen geliştirdi

$4 \quad 20$

4-9-14-19

Okuma becerimi geliştirmedi

3

2-6-10

d. Konuşma becerisine etkisi

Konuşma becerimi son derece geliştirdi

$6 \quad 30$

$1-2-4-5-12-19$

Konuşma becerimi kısmen geliştirdi

$6 \quad 30$

6-7-9-17-18-20

Konuşma becerimi geliştirmedi

$8 \quad 40$

$3-8-10-11-13-14-15-16$

e. Diğer dil becerilerine etkisi

Dil bilgisi seviyemi geliştirdi

$8 \quad 40$

$1-2-3-9-12-13-19-20$

Kelime hazinemi geliştirdi

$2 \quad 10$

$3-17$

Telaffuzumu geliştirdi

$1 \quad 5 \quad 1$

Hazırlık programının İngilizce yeterlik düzeyine etkisi ile ilgili öğrenci görüşleri incelendiğinde öğrencilerin zorunlu hazırlık programının en çok yazma ve okuma becerisi üzerinde olumlu etkiye sahip olduğu yönünde görüş bildirdikleri tespit edilmiştir. Tablo 5 incelendiğinde öğrencilerin tamamına yakınının (\%90) zorunlu hazırlık programının yazma becerisini son derece geliştirdiği, sadece bir (\%5) öğrencinin yazma becerisini kısmen geliştirdiği ve yine sadece bir (\%5) öğrencinin bu beceriyi geliştirmediği yönünde görüş bildirdiği görülmektedir. Yazma becerisi ile ilgili örnek öğrenci görüşleri aşağıda verilmiştir:

Ö3. "Zaten bütün yıl bize yazmayı ögretiyorlar gramer olarak yani o da bayağ iyiydi. Writing (yazma becerisi) konusunda bayağı geliştirdim kendimi."

Ö4. "Evet onda da (yazma becerisi) çok faydası oldu hocam. Çünkü vizelerde writingler (yazma becerisini ölçen bölüm) var ve bir şsekilde düzgün kelimelerle güzel bir paragraf oluşturmamı gerekiyor. Onu da işte gerekli işte hımm yardımcı fiillerle onu da düzelttiğimi düşünüyorum yani." 
Ö5. "Hımm yazmayı yapamıyorum. Olmuyor yazma yani. Yani geliştirmem lazım."

Ö7. "Yazma okumadan daha iyi gelişti yani. Daha mesela kelimeleri üst seviyede kurmaya başladım. Hımm sınavlarda (kelime sayısı) yüz yirmi çıkarken yüz otuz, yüz kırk çıkartabiliyorum artık. Bayă̆ı gelişti bence."

Ö9. "Yazmamı geliştirdim açıkçası hani etkinlik bayağı yaptık bu konuyla ilgili derste. Sinavlarda da güzel geçiyor. Çok faydası oldu bana yazma konusunda sene başından beri. Çok geliştirdim bence."

Ö11. "Yazma beceresini de geliştirdi ama ne düzeyde tartışılır bence. Biraz geliştirdi diyeyim."

Ö15. "Yazma becerisinde de yine başta çok eksiktim. O derslerde öğrendiğimiz aaa konular ondan sonra zaten hocalarımı sayesinde o konular hakkında devamlı bir writing (yazma etkinlikleri) yapmaya çalıştık. Onun dışında derslerde ögrendiğimiz hani kelimelerin sonradan onu yazma şeklimiz falan bayağı geliştirdiğini düşünüyorum. Onun üzerinde zaten hocalarımız biraz daha fazla durdu. Bu kadar yani."

Görüşmelerle elde edilen veriler incelendiğinde yazma becerisinden sonra hazırlık eğitiminin en çok okuma becerisini geliştirdiği tespit edilmiştir. Okuma becerisi ile ilgili olarak öğrencilerin çoğunun (\%65) hazırlık programının okuma becerilerini son derece geliştirdiği, bazı öğrencilerin (\%20) okuma becerilerini kısmen geliştirdiği ve az sayıda öğrencinin (\%15) okuma becerilerini geliştirmediği şeklinde beyanlarda bulundukları görülmektedir. Örnek öğrenci görüşleri aşağıdaki gibidir:

Ö4. "Ya aşă̆l yukarı bir faydası olmuştur (okuma becerisine) ama, zaten yani çok böyle absürt (olağan üstü) bir derecede değişen bir şey olduğunu sanmiyorum."

Ö6. “Okuma beceresini etkilemedi. O biraz da benden kaynakl. Üstüne durursak tabi olur da yani biraz daha gramer kelime ezber olduğu için okumaya önem veremedim. Okuma aynı kaldı nerdeyse."

Ö7. "Eskiden anlamıyordum yani hiç. Şimdi hani hımm etkinliklerde anlamaya başladım. Hani Ingilizcem (okuma becerim) bayă̆ı bir gelişti."

Ö9. "Eee. Geliştirdi ama çok fazla değil. Hani mesela paragraf olsun mesela kitap ödevleri verilebilirdi bize işte. Ders içinde daha fazla paragraf aktiviteleri yapabilirdik. Hani sınavda çıkan tarzda hiç çözmedik mesela sene içerisinde bu olabilirdi."

Ö10. "Zaten okuduğumu anlıyordum. Hala anllyorum. (Hazırlığın etkisi olmadı) Olmadl."

Ö15. "Zaten en çok beni en çok o anlamda etkiledi. Mesela okuduğumu ilk başta hiç anlayamazdım. Şimdi bayağı kendimi geliştirdiğimi düşünüyorum. Sinavlarda olsun vizelerde falan baktığımda hiç anlayamazdım. Şu an bayağı hani kendimi geliştirdiğimi düşünüyorum. Az önce tekrar olduk aynısını (sene başında yapılan muafiyet sınavi) bu daha bir kolay duruma geldi benim için. Hem de aynı zamanda mesela birçok da hani hocalarımızın bize tavsiyeleri oldu film izleyin şey yapin. Ben mesela Ingilizce çeviremezdim, dizilere falan başladım. Hani hocalarımızın da tavsiyeleri ile en çok bu konuda kendimi geliştirdiğimi düşüyorum." 
Ö19. “Okuduğumuzu anlamaya etkisi... Yani hımm burada daha çok bence hani ĕger çalışmalar yaparsak olabilir fakat daha çok grammer (dilbilgisi) ögreniyoruz. Bence okuduğunu anlaman için zannımca kitap okuman lazım. Ingilizce olarak kitap, hikâyeler okumamı lazım. Onun haricinde pek bir kitap da okumadı̆̆ımıza göre, ha parçalar var, kısa kısa parçalar illa ki faydası oluyor da ama oturup bir günde bir saat veya üç, beş, altı saat ve çevirerekten okumamı lazım."

Öğrenciler hazırlık programının dinleme ve konuşma becerileri üzerinde yazma ve okuma becerilerine göre daha az olumlu etkiye sahip olduğu yönünde görüş bildirmişlerdir. Buna göre Tablo 5 incelendiğinde bazı öğrencilerin (\%25) hazırlık programının dinleme becerisi üzerinde son derece olumlu etkiye neden olduğu, bunun yanında öğrencilerin yarısına yakınının (\%45) hazırlık programının dinleme becerisi üzerinde kısmen olumlu etkiye neden olduğu görüşüne sahip oldukları görülmektedir. Ayrıca bazı öğrenciler (\%30) hazırlık programının dinleme becerisi üzerinde olumlu etkiye neden olmadığ yönünde görüş bildirmektedirler. Dinleme becerisi ile ilgili örnek öğrenci görüşleri aşağıda verilmektedir:

Ö1. "Dinlemem gelişti, ama çok gelişmedi çünkü dinlemedim, dinlemede sıkıntı yaşıyorum."

Ö4. "Listeningde (dinleme etkinliklerinde) yakalayabiliyorum artı. Mesela kelimeyi dinlediğimde normalde iki üç seferde yakaladı̆̆ım şeyi şimdi teke indirdiğimi düşünüyorum."

Ö5. "Çok hılı konuşmadıkları sürece anlıyorum. Üst düzey hızlı olmadığı sürece anllyorum. Olumlu bence etkisi."

Ö6. “Önce tabi buna önem vermiyorduk lisede. Ama burada listening (dinleme etkinlikleri) olduğu için illa ki üstüne düşülüyor yani. Ekstra kendim bir çaba sarf etmiyorum ama derste de işte tahtadan bilgisayardan dinleyince iyi oluyor. Alıştık yani. Evet, ama zor seviyelerde yine anlayamıyorum."

Ö7. "Dinlediğimi hani bu birkaç ayda iyice gelişmeye başladt. Daha önce yoktu tabi. Hani tabi yazmaya göre biraz daha yavaş. Evet, biraz gelişti."

Ö9. "Ya onda da gelişme var ama söylediğim gibi çok iyi değil yani beklediğim gibi değil."

Ö16. "Tabii ki de çok etki etti. Hani dönem başından beri ilk başlarda çok hızlı geliyordu ama şu an çok hızlı gelmiyor, anliyorum dinlediğimi."

Ö17. "Faydası tabi ki faydalı oldu. Yani mesela sene başındaki sinava göre baya kolay yaptım o geçen ki şeyi (testi). Özellikle listening (dinlediğini anlamaya yönelik sorular) bölümü yani. Öyleydi. ... Dinleme işte dediğim gibi çok gelişti, tabi daha da gelişmesi lazım. En çok listening (dinleme becerisi) gelişti bence."

Ö19. "Dinleme... Benim şahsi olarak bir sılkıntım var herhalde. Ben halen yani tam olarak kelimeleri alamıyorum. Mesela çok hızlı konuşuyorlar, gerçi yaptığımız şeyde (testte) gayet güzel artık yavaş yavaş konuştuğu için anlaşıllyordu. Fakat hızlı konuştuğunda kelimeleri alamıyorum aradan."

Ö20. “Onu (dinlediğimi) anlıyorum. Hani ilk başlarda böyle çok karıştırlyordum ama şimdi gayet iyi anllyorum." 
Konuşma becerisi ile ilgili olarak ise, öğrencilerin bazılarının (\%30) hazırlık programının konuşma becerilerini son derece geliştirdiği ve yine bazı öğrencilerin (\%30) konuşma becerilerini kısmen geliştirdiği görüşüne sahip oldukları görülmektedir. Öğrencilerin yarısına yakınının (\%40) ise hazırlık programının konuşma becerilerini geliştirmediği yönünde görüş bildirdikleri görülmektedir. Hazırlık programının İngilizce konuşma becerilerine etkisi ile ilgili öğrenci görüşlerinden bazıları aşağıda verilmektedir:

Ö4. "Yani konuşma benim için yani yüzde seksen, doksan etkili olmuştur. Çünkü genelde sinıfin haylaz ögrencisiyim. Ve hoca genelde beni tahtaya çıkartıp konuşturuyor. Yani ister istemez her zaman her gün prova yapıyormuş gibi oldum. Ve şu zamana kadar speakinglerde (konuşma sınavlarında) hep tam puan aldım. Gelişti evet."

Ö8. “Konuşma, ben Türkçe konuşuyorum derslerde genelde. Çok da ilerletmedi, ben anlık çeviri yapamıyorum. Pek etkilemedi."

Ö9. "Konuşma ilerleme kaydettim. Az çok söyleneni de anlayabiliyorum ama şu an için fena değil ama geliştirmem şart yani."

Ö10. "Hazırlı̆̆ın etkisi sifır bence. Speaking sınavı (konuşma sınavı) dışında konuşmuyoruz."

Ö13. "Hani konuşmada benden de kaynaklanıyor tabi ki biraz ama daha çok bir etkinlik falan olsa sadece konuşmak için mesela bir ders falan olsa daha faydalı olabilir. Ama bende açıkçası çok etkili olmadı. Konuşurken falan zorlanıyorum."

Ö14. "Konuşma becerimin pek geliştiğini söyleyemem. Hatta aksine geriledi diyebilirim bazı konularda çünkü tabi yine materyaller ile ilgili üç kitap bitirmemiz gerekiyordu bir sene içerisinde speaking (konuşma etkinlikleri) yapamadık pek. Öyle düşünüyorum. ..."

Ö15. “Konuşma becerisinde aslında hala çok iyi olduğum söylenemez. Çünkü dediğim gibi çok fazla bir aktivitemiz olmuyor sınıf ortamında. Hani biz kendimiz arkadaşlarımızla da oturup hadi gel speaking (konuşma pratiği) yapalım demiyoruz. Bu konuda bir eksiğim var. Ama oturup kendi kendime bir çalıştı̆̆ım zaman hani az çok bir şeyler yapabiliyorum ama hani ilk baştaki speaking vizelerimizden (vizedeki konuşma sınavi) şu ankine kendime çok fazla bir şey kattı̆̆ımı düşünemiyorum. Çünkü dediğim gibi eksikliklerim oluyor yani." Ö19. "Konuşmaya etkisi oluyor, çünkü hocalar genelde İngilizce konuşturduğu için, speaking alıştırmaları (konuşma becerisini geliştirmeye yönelik etkinlikler) olduğu için etkisi çok oldu."

Ayrıca zorunlu hazırlık programının dört temel dil becerisi üzerindeki etkisi dışında dil bilgisi, kelime hazinesi ve telaffuz gibi beceriler üzerinde de olumlu etkiye sahip olduğunu ifade eden öğrenci görüşleri mevcuttur. Buna göre öğrencilerin yarısına yakını (\%40) programın İngilizce dil bilgisi seviyelerini geliştirdiğini belirtirken, az sayıda öğrencinin (\%10) programın İngilizce kelime hazinelerini geliştirdiği ve bir (\%5) öğrencinin de İngilizce telaffuzunu geliştirdiği yönünde görüş bildirdikleri görülmektedir. Örnek öğrenci görüşlerine aşağıda yer verilmektedir:

Ö3. "Yani gramer konusunda çok şey kattı. Ama çoğu zaman yani sadece gramer ve writinge (yazma becerisine) dayalı olduğu için yani spikinge (konuşma becerisine) biraz daha şey yapılsa (ağırlık verilse) daha iyi olur 
ayrıca. Yani gramer konusunda oldu. Şöyle ya kelimelerden daha iyi şey yapmaya başladım. Kelimeleri daha iyi bulmaya başladım. Sonra anlamları daha iyi çıkarabildim. Daha faydalı oldu kesinlikle bu sene."

Ö17. "Dinleme işte dediğim gibi çok gelişti, tabi daha da gelişmesi lazım. Okuma, ya kelime olarak çok şey kattı tabi. Konuşma, ya konuşma bölümlerinde önceden hiç yapamazdım, şimdi biraz daha iyi. En çok listening (dinleme becerisi) gelişti bence."

Ö1. "Telaffuzlarım gelişti. Yani okuma konusunda daha akıcı okuyorum, önceden mesela duruyordum bazı yerlerde, yani okuyamıyordum kelimeyi artık daha akıc okuyorum."

Ö12. "Bir de şey açısından gramer açısından daha etkili oldu. Çünkü daha fazla bunun üzerinde duruluyor. Ne kadar grameri eleştirsem de bunun üzerinde duruluyor yani."

Ö20. "Bence gramerimi geliştirdi onun dışında zaten benim ya hani eskiden hani lisede ortaokulda da İngilizcem yüksekti. Çok fazla hani speakinge (konuşma becerisine) ya da listeninge (dinleme becerisine) çok fazla bir etkisi, listeningde etkisi oldu, hani listeningde daha rahat anlyorum şimdilerde. Ama hani speakinge çok fazla bir etkisi olmadı. Gramer açısından kendimi geliştirdim. Bu şekilde."

\section{Hazırlık programı ile ilgili eleştiri ve öneriler}

Öğrencilerin zorunlu hazırlık programı ile ilgili eleştiri ve önerilerinin belirlenebilmesi amac1yla görüşme formunda öğrencilere yöneltilen soru "İngilizce hazırlık programı ile ilgili eleştiri ve önerilerin nelerdir?” şeklinde ifade edilmiştir. Öğrencilerin zorunlu hazırlık programına yönelik eleştiri ve önerileri ile ilgili bulgular ile bulgulara ilişkin frekans dağılımları ve yüzde değerleri Tablo 6'da verilmiştir. 
Tablo 6

Hazırlık Programı İle İlgili Eleştiri Ve Öneriler

\begin{tabular}{|c|c|c|c|}
\hline Hazırlık programı ile ilgili eleştiri ve öneriler & $f$ & $\%$ & Katılımcılar \\
\hline \multicolumn{4}{|l|}{ a. Dersler } \\
\hline Konuşma becerisi üzerinde daha çok durulmalı & 9 & 45 & $3-7-9-11-12-14-15-16-18$ \\
\hline Dil bilgisine çok ağırlık veriliyor & 7 & 35 & $1-3-6-11-12-16-19$ \\
\hline Kitaba çok ağırlık veriliyor & 6 & 30 & $3-7-8-13-14-20$ \\
\hline Ders programında her beceri ayrılmalı (skill-based) & 5 & 25 & $5-13-15-16-20$ \\
\hline Rol yapma (role-play) etkinlikleri artırılmalı & 3 & 15 & $4-7-10$ \\
\hline Ders süreleri çok uzun tutuluyor & 3 & 15 & $2-4-8$ \\
\hline Haftalık ders sayısı artırılmalı & 2 & 10 & $5-16$ \\
\hline Yazma becerisi üzerinde daha çok durulmalı & 2 & 10 & $16-18$ \\
\hline Alan dersleri olmalı & 1 & 5 & 19 \\
\hline Dinleme becerisi üzerinde daha çok durulmalı & 1 & 5 & 12 \\
\hline Dersler çok sıkıcı & 1 & 5 & 10 \\
\hline \multicolumn{4}{|l|}{ b. Öğretim elemanları } \\
\hline Yabancı hocalar olmalı & 7 & 35 & $6-7-9-15-17-18-19$ \\
\hline Öğretim elemanları ikinci dönemde değişmemeli & 2 & 10 & $6-10$ \\
\hline Hocalar bize değer veriyor & 1 & 5 & 8 \\
\hline Derse giren öğretim elemanı sayısı çok fazla & 1 & 5 & 11 \\
\hline Yabancı hocalarla anlaşamıyorum & 1 & 5 & 16 \\
\hline \multicolumn{4}{|l|}{ c. Değerlendirme } \\
\hline Geçme notu çok yüksek & 2 & 10 & $1-5$ \\
\hline Ders içi durum yılsonu notunu daha çok etkilemeli & 1 & 5 & 7 \\
\hline \multicolumn{4}{|l|}{ d. Diğer } \\
\hline Kur sistemi olmalı & 4 & 20 & $10-14-15-20$ \\
\hline Konuşma kulüpleri olabilir & 2 & 10 & $11-12$ \\
\hline Kur sisteminin olmaması güzel & 1 & 5 & 6 \\
\hline
\end{tabular}

Zorunlu hazırlık programı ile ilgili eleştiri ve önerilere yönelik görüşme verileri incelendiğinde öğrencilerin eleştiri ve önerilerinin çoğunlukla dersler, öğretim elemanları ve değerlendirme alt temaları altında toplandığı görülmektedir. Dersler ile ilgili öğrenci görüşleri ayrıntılı olarak incelendiğinde öğrencilerin yarısına yakınının (\%45) zorunlu hazırlık programı kapsamında konuşma becerisi üzerinde daha çok durulması gerektiği ve yine öğrencilerin yarısına yakınının (\%35) dil bilgisine çok fazla ağırlık verildiği yönünde görüş bildirdiği görülmektedir. Bazı öğrenciler (\%30) dersler kapsamında kitaba çok fazla ağırlık verildiğini ve bazı öğrenciler (\%25) ders programında her becerinin ayrı olması gerektiği yani beceri odaklı (skill-based) bir programın gerektiğini belirtmektedirler. Az sayıda öğrenci (\%15) derslerde rol yapma 
(role-play) etkinliklerinin artırılması gerektiğini ve ders sürelerinin çok uzun olduğunu ifade etmektedirler. Ayrıca az sayıda öğrenci (\%10) haftalık ders sayısının artırılması gerektiğini ve yazma becerisi üzerinde daha çok durulması gerektiğini belirtmektedirler. Bunların dışında sadece birer öğrenci (\%5) zorunlu hazırlık programında İngilizce alan dersleri olması gerektiğini, dinleme becerisi üzerinde daha çok durulması gerektiğini ve derslerin çok sıkıcı olduğunu belirtmektedirler. Öğrenci görüşlerinden bazıları aşağıda verilmektedir:

Ö2. "Yani ders araları biraz daha fazla olabilirdi. Beş dakika mola oluyor. İki saat ders oluyor."

Ö3. "Ya şöyle speakinge (konuşma becerisine) daha fazla önem verilmesini ben tavsiye ederim. Çünkü yani konuşamayan insan rahat yazamaz da bence. Ya konuşmak için ögreniyor zaten çoğu kişi Ingilizceyi. Yani onun haricinde ders süreleri hep aynı da içerikleri hep aynı üç kitap işledik üçü de tekrar ediyor hep. Yani hep aynı konuları görüyoruz o biraz sıkıcı. Bir zaman sonra insanların odağ değişiyor artık şey yapamıyorlar, odaklanamıyorlar. Öyle yani çok fazla sıkıcı şey var. Yani speakinge ă̆ırlık verilmesi başka bir şeye değil."

Ö4. "Ya hocam şunu söyleyebilirim. Kesinlikle faaliyet çok önemli. Kesinlikle böyle bir küçük etkinlikler küçük tiyatrolar sınıfta yapabiliriz. Bunlar ilk dönem daha fazlaydı. İkinci dönem hocalarımız değişti. İki, üç hocamız farklılaştı. ... Başka hımm saatlerimiz hocam bazen yoğun oluyor. Şimdi blok ders yapıyoruz, hani bir süre sonra kopuyorum yani. Blok hocam durumuna göre değişiyor. Hani etkinlik içinde bir blok olsa problem yok ama iki saat ben oturamiyorum sandalyede yani."

Ö5. ... "Bir de ders sayısı bence arttırllmalı. Şey olabilir, gün gün konular ayrlabilir, bir gün dinleme, bir gün yazma (skill-based) o zaman daha etkili olabilir. Çünkü biz ona hazırlıklı gelirsek belki daha iyi olabilir."

Ö11. "Ve biz daha çok gramer (dilbilgisi) üstündü duruyoruz. Bence speaking (konuşma becerisi) ya da listening (dinleme becerisi) üstüne daha fazla durulması gerekirdi diye düşünüyorum. Ve ekstra dersler için listening, speaking vs. gibi bunlar için bence bir topluluk tarzı bir şey geliştirilebilir. Çünkü okulumuzda yeteri kadar yabancı öğrenci var. Konuşmak ya da yazmak için bir şeyler yapılabilir diye düşünüyorum. Aklıma gelenler bunlar."

Ö12. "Hımm benim tavsiyelerim daha fazla listening (dinleme becerisi) ve speaking (konuşma becerisi) üzerinde durulmall. Daha fazla konuşma aktif edebileceğimize ve derdimi anlatabilsem yeterli deniliyor. Grameri çok fazla düşünülmemesini istiyorum. Bence bu sadece gramer üzerinde düşünmek öbürlerini eksik kllıyor. Bu benim eleştirim.”

Ö13. "Kitaplarda hani açıkçası gereksiz şeyler fazla. Kitapta daha çok değişiklikler olabilir. Az önce de dediğim gibi sade konuşma dersi, sadece dinleme dersi (skill-based) falan olabilir. Başka bilemiyorum."

Ö14. ... "Ve speakinge (konuşma becerisine) daha çok ăğllık verilmesi gerekiyor. Kitaptan çünkü zaten altı yedi senedir sırf müfredata göre hep kitaptan gidiyoruz. Speaking (konuşma etkinlikleri) yapıldiğı zaman daha faydalı olabilir. Öyle düşünüyorum yani ben." 
Ö16. "Eleştirilerim, bu kadar gramer ağırlıklı olmamall. Writinge (yazma becerisine) ve hani speakinge (konuşma becerisine) çok vakit verilmeli. Çünkü bizim işimiz, madem hani bir yılımızı kaybediyoruz bunlara yoğunlaşmalıyı diye düşünüyorum, ileride de bize gramer hani sormayacaklar bir makale yazarken veya çevirirken. Eleştiri olarak dediğim gibi, bu derslerin hani zaman klsıtı var. Hani haftada her gün ders alırken, bu derslerle yetinemiyoruz biz."

Öğrencilerin öğretim elemanları ile ilgili eleştiri ve önerilerine yönelik görüşleri incelendiğinde en yüksek frekansın (\%35) yüksekokulda derslere giren yabanc1 hocaların olması gerektiği ile ilgili olduğu görülmektedir. Bunun dışında az sayıda öğrenci (\%10) öğretim elemanlarının ikinci dönemde değişmemesi gerektiğini belirtirken birer öğrenci (\%5) hocaların öğrencilere değer verdiği, derse giren öğretim elemanı sayısının çok fazla olduğu ve yabancı hocalarla anlaşamadığı yönünde görüş bildirmektedir. Örnek öğrenci görüşleri şöyledir:

Ö6. "Yani önceki dönemlerde yabancı hocalar varmış. Onun çok etkisi oluyormuş. Biz ondan mahrum kaldık. Öyle göremedik tabi nasıl olduğunu ama iyi diyorlardl. Olsa daha iyi olurdu tabi. Illa ki etkili olurdu. Hocalar sürekli değişmese daha iyi aslında. Birinci dönem üç tane hocamız vardl. Alıştık güzeldi. Ikkinci dönemde hocalarda iyiydi amma belli bir süreçte alışmak gerekiyor. Onun için biraz vakit kaybı oldu gibi. Değişmese de iyi olurdu yani slkıntı olmazdı."

Ö9. "Benim önerim özellikle gelecek sene eğer mümkünse yabancı hocaların gelmesi, konuşma adına anlama adın. ... Önerim bu şekilde yani özellikle yabancı hocalar."

Ö16. "Öneri olarak da bir de yabancı hocalarımı var, hani onlarla pek anlaşamıyoruz maalesef." ...

Ö19. ... "Onun haricinde hani yabancı bir hoca geçen sene yanlış değilsem varmış, Hani bir yabancı, dışarıdan gelen hani haftanın bir günü yabancı biriyle speaking (konuşma) aksan konusunda yararl olur, onun haricinde yapabileceğiniz yani bilmiyorum."

Öğrencilerin değerlendirme sistemi ile ilgili görüş ve önerileri incelendiğinde sadece iki (\%10) öğrenci geçme notunun çok yüksek olduğunu ve düşürülmesi gerektiğini belirtirken, bir öğrenci (\%5) de ders içi durumun yılsonu notunu mevcut durumdan daha çok etkilemesi gerektiğini belirtmektedir. Öğrenci görüşlerinden bazıları şöyledir:

Ö1. “Okulla ilgili, hazırlı işte dediğim gibi birincisi sınır 60'a çekilmeli, çünkü 70 yüksek bence. Eee ve zorunlu olmall ama alttan burakabilme gibi bir şey olursa daha iyi olur diye düşünüyorum."

Ö5. "Ya hocam geçme notu biraz yüksek bence. Yani cidden bizim bölümümüz yüzde otuz İngilizce ama geçme notu 70 yani biz yapamayacă̆ı gibime geliyor." ...

Ö7. "Ya tabi ben hani sinavlarda sürekli stres yapan heyecanlanan bir insanım ve hani tabi sınavlarda çalıştı̆̆ımın karşılı̆̆ını alamıyorum. Hani bilmiyorum daha nasıl yapılabilir bilmiyorum ama hani etkinlikler daha da çoğaltıp hani mesela insan ögrencilerin çalışmasinı göz önüne alarak ilk önce sınav değil de çalışmalar göz önüne alınarak notları biraz daha arttırılmasını düşünüyorum." 
Öğrencilerin zorunlu hazırlık programı ile ilgili diğer görüşleri incelendiğinde bazı öğrencilerin (\%20) programda kur sistemi olması gerektiğini ifade ettiği görülürken sadece bir (\%5) öğrencinin kur sisteminin olmamasının güzel olduğunu belirttiği görülmektedir. Bunun dışında az sayıda öğrencinin (\%10) dersler dışında konuşma kulüpleri olması gerektiğini belirttikleri görülmektedir. Öğrenci görüşlerinden bazıları şöyledir:

Ö14. "Daha faydall olabilmesi için kesinlikle kur düzenine girilmeli. Yani ben başta bu yüzden çok hayal kırıklığına uğramıştım. Kur olacağını düşünüyordum. Yani seviye sinıfları. Pat diye hani ABC-123 türünden değil de başka bir yerden başlamak isterdim. Kesinlikle kur olmall yani. Kur düzeni olmall."

Ö15. ... "Ve sınıf düzeyleri farklı olabilir çünkü biz başta geldiğimizdeki seviye ile şu an ki seviyemiz çok farklı yani. Onun dışında aslında birazda üniversiteden kaynaklanan bir şey ama biraz da yabancı öğretmenlerin daha fazla olmasi gerektiğini düşünüyorum."

Ö20. "Bence öğrencilere sene başında girdikleri hazırlık sınavına göre, yani, seviyelendirmelisiniz. Çünkü şimdi hani bizim sinıfta hani Ingilizce hazırliğa sifirdan başlayanlar da var, orta derece olanlar da var, hani daha iyi derecede olanlar da var. Ve böyle çok fazla anlaşmazlık oluyor. Ingilizcesi sıfirdan başlayanlar bir süre sonra siknliyor dersten ve hani insanlar, sinıftakilerin dikkatini dağıtıyor. Bu çok hoş olmuyor. Yani kur sistemi gelebilir."

\section{Sonuç ve Tartışma}

$\mathrm{Bu}$ araştırma, Necmettin Erbakan Üniversitesi Yabancı Diller Yüksekokulu'nda sunulan zorunlu İngilizce hazırlık programının etkililiğinin değerlendirilmesi amacıyla yürütülmüştür. Bu amaçla oluşturulan araştırma hipotezinin test edilmesi için akademik yılın başında yapılmış olan seviye tespit sınavı öğrencilerin İngilizce dinlediğini anlama, okuduğunu anlama ve dilin kullanımı ile ilgili gelişimlerinin analiz edilmesi amacıyla son-test olarak uygulanmıştır. Elde edilen verilere göre yeterlik sınavı ön test ve son test puan ortalamaları arasında anlamlı fark bulunmuştur. Buna göre bir yıllık zorunlu hazırlık programının öğrencilerin İngilizce dinlediğini anlama, okuduğunu anlama ve dilin kullanımı ile ilgili yeterlik seviyelerini anlamlı düzeyde geliştirdiği söylenebilir. Hazırlık programının öğrencilerin başarıları üzerindeki etkisine odaklanılarak değerlendirildiği sınırlı sayıda araştırmaya ulaşılabilmiştir. Seven (2004) tarafından yürütülmüş olan araştırmada elde edilen hazırlık programının öğrencilerin kelime, dil bilgisi, temel İngilizce, çeviri, okuma ve İngilizce başarı testi toplam puanlarında anlamlı düzeyde gelişime neden olduğu yönündeki bulguların bu araştırmanın sonuçları ile benzerlik gösterdiği söylenebilir. Bu araştırmada elde edilen nicel verilere dayanılarak bir yıllık hazırlık eğitiminin genel anlamda başarılı olduğu söylenebilir. Bu araştırmada nicel verilerin değerlendirilmesiyle elde edilen bu sonucun, sunulan zorunlu hazırlık programının etkililiği konusunda olumlu yönde fikir vermesine karşın tek başına değerlendirme yapmak için yeterli olmadığı ve mutlaka öğrenci görüşleriyle birlikte değerlendirilmesi gerektiği düşünülmüş ve bu amaçla öğrenci görüşlerini içeren nitel verilere başvurulmuştur.

Nicel verilerin derinlemesine araştırılması ayrıca hazırlık programının yazma ve konuşma becerilerine etkisinin de incelenerek İngilizceye yönelik genel bir değerlendirme yapılabilmesi amacıyla oluşturulan araştırma sorusu kapsamında 
öğrencilerin zorunlu hazırlık programının İngilizce başarıları (yazma, dinleme, okuma ve konuşma becerileri) açısından etkililiği ile ilgili algıları araştırılmıştır. Bu kapsamda elde edilen öğrenci görüşleri öğrencilerin hazırlık programına katılma amacı ve programdan beklentileri, zorunlu İngilizce hazırlık programının etkililiği ve öğrencilerin programdan memnuniyeti, hazırlık programının öğrencilerin İngilizce yeterlik düzeylerine etkisi ile öğrencilerin program ile ilgili eleştiri ve önerileri temaları altında toplanmıştır.

Öğrencilerin hazırlık programına katılma amaçları ve programdan beklentileri ile ilgili bulgular incelendiğinde öğrencilerin genel olarak programa katılma amaçlarının ve programdan beklentilerinin İngilizceyi iyi bir seviyede öğrenme, öğrenim görülen bölümün gerekliliği ve akıcı konuşma becerisi kazanma olduğu sonucuna ulaşılmıştır. $\mathrm{Bu}$ sonuca dayanılarak genel olarak öğrencilerin akademik amaçlı olarak hem öğrenim gördükleri bölümden mezun olabilmeleri hem de mezuniyet sonrası kariyer planlamaları açısından İngilizceyi iyi seviyede öğrenme ve konuşma amacıyla programa katıldıkları söylenebilir. Şen Ersoy ve Kürüm Yapıcıoğlu (2015) tarafından yürütülen araştırmada bu araştırma sonuçlarıyla benzer şekilde öğrencilerin özellikle kişisel gelişim ve kariyer planlamaları doğrultusunda hazırlık programına katıldıkları sonucuna ulaşılmıştır. Kaçar ve Zengin (2009) tarafından katılımcıların yarıdan fazlasının üniversite öğrencilerinin olduğu çalışma grubu ile yürütülen araştırmada katılımcıların çoğunlukla akademik amaçlı dil öğrenmek istedikleri ve bunu iletişim, bilim ve teknolojiden yararlanma ve zihinsel gelişim hedeflerinin izlediği ve konuşma becerisinin öğrencilerin hedefleri açısından öncelikli olduğu sonucunun bu araştırma ile benzerlik gösterdiği söylenebilir. Davras ve Bulgan (2012) tarafından yürütülen araştırmada meslek yüksekokulu zorunlu hazırlık sınıfı öğrencilerinin iş yaşamlarında İngilizcenin önemli rolü yönündeki algılarının bu araştırma bulgularıyla benzerlik gösterdiği söylenebilir. Özkanal ve Hakan (2010) tarafindan yürütülen araştırmada öğrencilerin çoğunun bölümlerinde öğretim dilinin İngilizce olmasından ötürü öğrenim gördükleri bölümün bir gereği olması ve İngilizcelerini geliştirmek nedenleriyle hazırlık programına katıldıkları sonucunun bu araştırma ile benzerlik gösterdiği söylenebilir.

Öğrencilerin hazırlık programının etkililiği ve programdan memnuniyet ile ilgili görüşleri incelendiğinde öğrencilerin çoğunlukla hazırlık programının etkili olduğu ve uygulanan programdan memnuniyet duydukları, ancak bazı ögrencilerin ise program ile ilgili bazı eksiklikler sebebiyle hazırlık programının kısmen etkili olduğu algısına sahip oldukları sonucuna ulaşılmıştır. Bu araştırmada öğrencilerin çoğunlukla programdan memnun olmaları programın etkililiğinin açısından olumlu bir göstergedir. Ancak, bazı öğrenciler tarafından programın kısmen etkili görülme sebeplerinin ve eksikliklerin programın iyileştirilmesi yönünden son derece önemli bulgular olduğu düşünülmekte ve programa ilişkin eleştiri ve öneriler ile ilgili sonuçların tartışıldığ bölümde ayrıntılı olarak ele alınmaktadır. Alan yazın incelendiğinde uygulanan programın etkililiği ile ilgili olumlu ve olumsuz öğrenci algılarını içeren araştırma sonuçları mevcuttur. Toker (1999) tarafından yürütülen çalışmada hazırlık programı öğrencilerinin neredeyse tamamının mevcut hazırlık programından memnuniyet duymadıkları sonucuna ulaşılmıştır. Bu nedenle öğrencilerin İngilizce seviyelerindeki farklılık, görsel işitsel araçların tedarik edilmesi, öğrencilerin ihtiyaçları ve ders süresi gibi faktörlerin program tasarımında göz önünde bulundurulmasının gerekliliği belirtilmiştir. Şen Ersoy ve Kürüm Yapıcıoğlu (2015) tarafından yürütülen araştırmada bu araştırmada olduğu gibi 
öğrenci görüşleri arasında az da olsa farklılıklar olduğu tespit edilmiş ve bu araştırma sonuçlarıyla benzer şekilde öğrencilerin çoğunun hazırlık eğitimini yeterli bulduğu bildirilmiştir. Özkanal ve Hakan (2010) bu araştırma bulgularıyla benzer şekilde bazı eksiklikler dışında öğrencilerin programdan memnun oldukları, öğretiminin etkili olduğu ve öğretmenlerin başarılı oldukları yönünde sonuç bildirmektedirler. Coşkun (2013) bu araştırma ile benzer şekilde uygulanan programın geliştirilmesi gereken unsurlarının bulunduğuna dair sonuç bildirmektedir. Davras ve Bulgan (2012) erkek öğrencilerin kadın öğrencilere göre programı ihtiyaçlarını karşılama açısından daha yeterli buldukları yönünde sonuç bildirmektedirler. Gerede (2005) tarafından yürütülen araştırmada hazırlık programı öğrencilerinin çoğunun genel İngilizce açısından programın ihtiyaçlarını karşılamada yeterli düzeyde olduğu ancak akademik amaçlı ihtiyaçlarını karşılamada yetersiz kaldığı sonucuna ulaşılmıştır. Kırkgöz (2009) tarafından gerçekleştirilen araştırmada ise öğrenciler kendilerine öğretilenle bölüm derslerinin gereklilikleri arasında uyum olmadığı, başka bir deyişle programın bölümlerinde kendilerinden beklenen dil becerileri açısından ihtiyaçlarını karşılamadığı yönünde sonuç bildirilmektedir.

Hazırlık programının dil yeterlik düzeyine etkisi ile ilgili bulgular incelendiğinde öğrencilerin dört dil becerisi ile ilgili görüşlerinin farklılaştığı görülmüştür. Öğrencilerin zorunlu hazırlık programının en çok yazma ve okuma becerilerini geliştirdiği, dinleme ve konuşma becerilerini ise yazma ve okuma becerilerine göre daha az geliştirdiği algısına sahip oldukları görülmüştür. Programın dört temel dil becerisi üzerindeki etkisi dışında dil bilgisi, kelime hazinesi ve telaffuz gibi beceriler üzerinde de olumlu etkiye neden olduğuna dair öğrenci görüşleri mevcuttur. Bu bulgulara göre zorunlu İngilizce hazırlık programının en çok yazma ve okuma becerileri üzerinde olumlu etkiye sahip olduğu, dinleme ve konuşma becerilerinin geliştirilmesinde ise yazma ve okuma becerilerine göre daha az olumlu etkiye sahip olduğu söylenebilir. Bu araştırmada konuşma becerisi ile ilgili olarak elde edilen sonuç Davras ve Bulgan (2012) tarafından gerçekleştirilen çalışmada meslek yüksek okulu İngilizce hazırlık eğitiminde konuşma becerisinin kazandırılmasında bazı eksikliklerin olduğu sonucuyla benzerlik göstermektedir. Mede ve Uygun (2014) tarafından yürütülen araştırmada ise bu araştırma bulgularından farklı olarak öğrencilerin hazırlık programının dört dil becerisini eşit düzeyde geliştirdiğine dair görüş bildirdikleri görülmektedir. $\mathrm{Bu}$ araştırmada öğrencilerin hazırlık programının en çok yazma ve okuma becerilerini geliştirdiği bulgusu ile farklı bir şekilde Toker (1999) hem öğretim elemanlarının hem de öğrencilerin hazırlık programında okuma becerisi üzerinde daha çok durulması gerektiğini vurguladıkları görülmektedir. $\mathrm{Bu}$ araştırmada öğrencilerin çoğunun programın okuma becerilerini son derece geliştirdiği algısına sahip olmalarına rağmen bazı öğrencilerin kısmen geliştirdiği ve az sayıda öğrencinin de okuma becerilerinin gelişmediği yönündeki algıları Mede ve Uygun (2014) ile Coşkun (2013) tarafından da belirtildiği üzere programa ekstra okuma etkinliklerinin eklenmesi yoluyla dikkate alınabilir. Grabe ve Stoller (2001), okumanın dil öğrenenler için başlıca bağımsız öğrenme yolu olması nedeniyle belki de en önemli akademik dil becerisi olduğunu vurgulayarak okuma becerisinin akademik hayattaki önemini belirtmektedir. Ayrıca öğrencilere akıcı okuma becerisi kazandırılması için daha çok fırsat sunma, sınıf içinde ve dişında kapsamlı okuma etkinliklerinin bir rutin haline getirilmesi, okuduğunu anlama amacıyla gerekli becerilerin öğrenme sürecinde ele alınması, okuma konusunda 
öğrencilerin motive edilmesi ve biliş üstü farkındalık ve strateji öğrenimi gibi konulara odaklanılarak öğrencilerin stratejik okuyucular olmalarına yardım edilmesi gibi uygulamalarla öğrencilerin okuma becerisine dair akademik ihtiyaçlarının karşılanmasına yardımcı olunabileceğini belirtmektedir.

Zorunlu hazırlık programı ile ilgili eleştiri ve önerilere yönelik bulgular incelendiğinde öğrencilerin eleştiri ve önerilerinin çoğunlukla dersler, öğretim elemanları ve değerlendirme alt temaları altında toplandığı görülmektedir. Dersler ile ilgili öğrenci görüşleri çeşitlilik göstermekle birlikte frekansı en yüksek bulguların konuşma becerisi üzerinde daha çok durulması gerektiği ve dil bilgisine programda çok fazla ağırlık verildiği yönünde olduğu görülmüştür. Ayrıca kitaba çok fazla ağırlık verilmesi ve rol yapma etkinliklerinin arttırılması yönündeki görüşlerin de aslında programda konuşma becerisine daha çok ağırlık verilmesi gerektiğine dair bulguyu destekler nitelikte olduğu düşünülmektedir. Bu anlamda dersler konusundaki eleştiri ve öneriler ile ilgili en önemli bulgunun programda dil bilgisine çok fazla ağırlık verilmesi ve konuşma becerisinin programda istenilen yoğunlukta olmayışı olduğu söylenebilir. Öğrencilerin programda konuşma becerisinin ihmal edildiği görüşünün Lazaraton (2001) tarafından belirtildiği üzere konuşmanın en temel iletişim şekli olması nedeniyle bir dili konuşma yeteneğinin o dili bilme ile eş anlamlı olarak algılanmasından kaynaklandığı düşünülmektedir. Araştırmacıya göre İngilizcenin yabancı dil olarak öğretildiği ortamlarda motivasyon eksikliği, ana dil kullanımı, kalabalık sınıflar, programda bu beceriye önem verilmemesi ve İngilizcenin öğretim elemanının ana dili olmamasından kaynaklanan nedenler dolayı konuşma becerisinin geliştirilmesinde sıkıntılar yaşanabilmektedir. $\mathrm{Bu}$ araştırmada konuşma becerisindeki bu eksikliğin kullanılan ders kitabının İngilizcenin yabancı dil olarak öğretildiği ve sınıf dışında günlük hayatta kullanma imkanının olmadığı bir ortamda konuşma becerisini geliştirme açısından yetersiz kaldığı ve sınıf içerisinde konuşma becerisinin gelişimine yönelik kullanılabilecek materyallerin azlığından kaynaklandığı düşünülmektedir. Benzer şekilde Coşkun (2013) tarafından yürütülen araştırmada hazırlık programı öğrencilerinin konuşma becerisine yönelik kullanılan öğretim materyallerinin yeterli olmadı̆̆ görüşünde olduklarını bildirmektedir. Ayrıca bu araştırmada elde edilen konuşma becerisinde istenilen düzeyde gelişim sağlanamadığına dair bulgunun bir diğer nedeninin öğretim elemanları tarafından kullanılan öğretim yöntem ve tekniklerinin konuşma becerisinin gelişmesi açısından yetersiz kalabileceği düşünülmektedir. Toker (1999) tarafından yürütülen araştırmada öğretim yönteminin öğrenme üzerinde büyük etkisinin olduğu ve ögrencilerin motivasyonunu olumlu veya olumsuz etkileyebileceği, farklı yöntemler kullanmak yoluyla farklı öğrencilerin ihtiyaçlarının karşılanmasının gerekliliğinin altı çizilmektedir. Bu araştırmada öğrencilerin konuşma becerisine ağırlık verilmesi ve rol-yapma gibi etkinliklerin arttırılması gerektiği yönündeki algılarının Coşkun (2013) tarafından yürütülen araştırmada hazırlık programı öğrencilerinin role yapma, tartışma ve sunum gibi etkinliklerin seyrek olarak uygulandığ görüşleriyle ve Özkanal ve Hakan (2010) tarafından yürütülen araştırmada öğrencilerin programda konuşma ve dinleme etkinliklerinin vurgulanması gerektiğine yönelik algılarıyla benzerlik gösterdiği söylenebilir. Benzer şekilde Lazaraton (2001) dil sınıflarında sözlü becerilerin geliştirilmesi için tartışma, hazırlıklı veya doğaçlama konuşma, rol-yapma, konuşma analizi ve sözlü günlük tutma gibi konuşma etkinliklerinin kullanılmasını tavsiye etmektedir. Ayrıca özellikle İngilizcenin yabancı dil olarak öğretildiği sınıflarda 
öğrencinin ilgisini çeken ve özgün materyallerin kullanımının faydalı olacağını belirtmektedir.

Bunların dişında, elde edilen önemli bulgulardan birinin programda her becerinin ayrı olması gerektiği başka bir deyişle programın beceri odaklı (skill-based) bir yapıya sahip olması gerektiği yönündedir. Öğrenciler, her beceriye yönelik ayrı bir ders olursa İngilizce düzeylerinin daha çok gelişeceğine inanmaktadırlar. Ancak alan yazın incelendiğinde dil öğretiminde beceri odaklı bir yaklaşım (skill-based approach) yerine daha bütünleşmiş yaklaşımların (integrated approaches) vurgulandı̆̆ görülmektedir. Celce-Murcia (2001) dil öğretiminde 1980'li yıllardan itibaren dört becerinin aynı çerçeve içerisinde beraber öğretimini teşvik eden bütünleşmiş yaklaşımlara doğru bir gidişe şahit olunduğunu belirtmektedir. Benzer şekilde Oxford (2001) ayrılmış beceri öğretiminin (segregated-skill instruction) insanların normal iletişimde kullandığı bütünleşmiş dil yapısına tamamen zıt olması ve dil öğretim uzmanlarının son yıllarda terk ettiği geleneksel dil öğretim programının bir parçası olması yönüyle eleştirmektedir. Ayrıca becerilerin ayrı ayrı öğretiminin mümkün olmasına rağmen akademik iletişim, mesleki ve günlük iletişimde dilin etkili bir şekilde kullanılması açısından başarı sağlamayacağının altını çizmektedir. Alan yazındaki bu açıklamalara dayanılarak programın beceri odaklı bir yapıya dönüştürülmesindense ögrencilerin konuşma ve dinleme becerisine yönelik ihtiyaçlarının bu yönde gerek sınıf içi etkinliklerin artırılması ve konuşma kulüpleri gibi sınıf dışı etkinliklerin sağlanması ve ek materyallerle karşılanmasının daha uygun olacağı düşünülmektedir.

Öğrencilerin öğretim elemanları ile ilgili eleştiri ve önerilerine yönelik veriler incelendiğinde yabancı hocaların olması gerektiği yönündeki görüşün en yüksek frekansa sahip olduğu görülmüştür. $\mathrm{Bu}$ bulgunun dersler ile ilgili olarak konuşma becerisi üzerinde daha çok durulması gerektiği yönündeki bulguyu desteklemesi yönünden de önem taşımaktadır. Öğrencilerin yabancı hoca taleplerinin İngilizce konuşma becerilerini geliştirme imkânı yaratacağ düşüncesinden kaynaklandığı düşünülmektedir. Şen Ersoy ve Kürüm Yapıcıoğlu (2015) tarafından yürütülen araştırmada bu araştırmanın bulgularıyla paralel olarak bazı öğrencilerin yabancı hoca beklentilerinin olduğu bildirilmektedir.

Değerlendirme sistemi ile ilgili bulgular incelendiğinde geçme notunun yetmiş olması öğrencilerin derslerde sıklıkla yakındıkları bir konu olmasına rağmen bu konuda öğrencilerin çok fazla görüş ifade etmedikleri görülmüştür. Bu durumun, araştırmanın nitel verilerinin yıl sonuna yakın bir zamanda toplanmasından dolayı öğrencilerin yetmiş olan geçme notu fikrine düşünce olarak alışmalarından kaynaklandığ düşünülmektedir. Ancak, az sayıda öğrenci tarafindan ifade edilmesine rağmen geçme notunun çok yüksek olduğu ve danışman hocaların yıl süresince öğrencilerin derse katılım durumunu yansıtan ders içi durum notunun yıl sonu notu üzerindeki etkisinin artırılması gerektiği yönündeki görüşlerin önem arz ettiği düşünülmektedir. Bu anlamda Kasım 2017 tarihli Necmettin Erbakan Üniversitesi Yabancı Diller Yüksekokulu Yabancı Dil Öğretimi ve Yabancı Dille Öğretim Yönetmeliği’nde Değişiklik Yapılmasına Dair Yönetmelik (2017) gereğince ilgili yönetmeliğin 1. Maddesinin 7. Bendinde yapılmış olan "Hazırlık sınıfında okuyan ve devam koşulunu sağlayan öğrencilerden yıl içi not ortalaması 80 ve üzeri olanlar final sınavına girmeyebilir. Bu öğrencilerin yıl içi not ortalamaları genel başarı notu olarak kabul edilir.” şeklindeki değişikliğin öğrencilerin değerlendirme sistemine yönelik bu taleplerinin okul yönetimi 
tarafından dikkate alındığının göstergesidir. $\mathrm{Bu}$ durumun yıl süresince öğrenci motivasyonunu önemli düzeyde arttıracağı düşünülmektedir.

Bunların dışında eleştiri ve öneriler ile ilgili önemli bulgulardan bir tanesi kur sistemi olması gerektiği yönündeki algıdır. Öğrencilerin bu önerilerinin sınıflarında farklı İngilizce seviyelerine sahip arkadaşlarının olması ve bu durumun da derslerden faydalanma açısından sorun yarattığı fikrinden kaynaklandığı düşünülmektedir. Toker (1999) tarafından yürütülen çalışmada benzer şekilde hazırlık programı öğrencilerinin tamamına yakını seviye gruplarının oluşturulması gerektiğini belirtmekte ve bu durumun da motivasyonu pozitif yönde etkileyeceği vurgulanmaktadır. Yine Şen Ersoy ve Kürüm Yapıcıoğlu'nun (2015) gerçekleştirdiği araştırmada öğrenci ve okutmanların düzey sınıfı yani kur sistemi olmayışını olumsuz bir durum olarak nitelendirdikleri bildirilmiştir. $\mathrm{Bu}$ araştırmada bazı öğrenciler kur sisteminin gelmesiyle oluşturulan seviye gruplarında İngilizce düzeylerini daha iyi geliştirebileceklerine inanmaktadırlar. Ancak, bazı öğrencilerin kur sistemi olması gerektiğine dair görüş bildirirken bir öğrencinin kur sisteminin olmamasından memnuniyet duyduğunu ifade etmesi seviye gruplarının oluşturulmasının bazı öğrencilere öğrenme sürecinde fayda sağlayacağı ancak özellikle düşük seviye gruplarında olan öğrencilerin bu durumdan motivasyon açısından negatif yönde etkilenebileceği gibi olumsuz etkilerinin de olabileceğini düşündürmektedir. $\mathrm{Bu}$ görüşle paralel olarak Coşkun (2013) yürütmüş olduğu araştırmanın sonucunda seviye gruplarının olduğu modüler sistemin uygulamadaki bazı sorunlar nedeniyle bırakılması gerektiği kanısına ulaşmıştır. Bu nedenle kur sistemine geçme fikrinin öğretim elemanı sayısı, sınıf sayısının yeterliliği ve öğretim sürecini etkileyebilecek diğer diğer fiziki şartlar ile öğrenim gören bütün öğrencilere bilişsel ve duyuşsal açıdan etkisi ayrıntılı olarak değerlendirilmelidir. Ayrıca konuşma kulüplerinin olmasının gerekliliği de belirtilen bir diğer görüştür. Bu bulgu yine programın konuşma becerisinin geliştirilmesi konusunda yetersiz olduğu konusundaki öğrenci algısına yönelik bulguyu destekler niteliktedir.

Programın etkililiği ve memnuniyet ile ilgili verilerde öğrencilerin çoğunun programdan memnun olduğu ancak, bazı öğrencilerin bazı eksikliklerinden dolayı kısmen memnun oldukları yönünde algıya sahip oldukları sonucuna ulaşılmıştı. Dolayısıyla öğrencilerin bahsetmiş oldukları bu eksikliklerin daha çok konuşma becerisine istenilen önemin verilmeyişinden kaynaklandığını söyleyebiliriz. Dil bilgisine istenilenden daha çok ağırlık verilmesi, rol-yapma etkinliklerinin artırılması, yabancı hocaların olması gerektiği gibi diğer birçok eleştiri ve önerinin altında yatan esas talebin konuşma becerisinin programda ihmal edildiğine dair algısını desteklediği ve bu görüş ile ilişkili olduğu düşünülmektedir. Bu anlamda genel ve özel hedeflerin ayrıntılı olarak belirtildiği resmi bir öğretim programının titizlikle hazırlanması, uygulanması ve sürekli olarak değerlendirilerek geliştirilmesi yoluyla bu eksikliklerin giderilebileceği ve başarının artırılabileceği düşünülmektedir. Benzer şekilde Toker'e (1999) göre hazırlık okullarında verilen İngilizce eğitimin istenen düzeyde olabilmesi için genel ve özel hedeflerin belirtildiği ve uzman kişiler tarafından hazırlanmış bir programın gerekliliği muhakkaktır.

\section{Öneriler}

Sonuç olarak, uygulanan programın öğrencilerin İngilizce yeterlik düzeylerini anlamlı düzeyde geliştirdiği, programın en çok yazma ve okuma becerileri üzerinde 
olumlu etkiye neden olduğu, dinleme ve konuşma becerileri üzerinde yazma ve okuma becerilerine göre daha az olumlu etkiye sahip olduğu, öğrencilerin genel olarak uygulanan programdan memnun oldukları, bunun yanında programın özellikle konuşma ve dinleme becerileri açısından eksikliklerinin bulunduğu söylenebilir. Araştırma bulguları ve ilgili literatür göz önünde bulundurularak hazırlık programının iyileştirilmesi amacıyla bazı önerilerde bulunulabilir. Öncelikle programda dil bilgisi öğretiminin sınırlandırılarak konuşma kulüpleri, yabancı hocaların derse girmesinin sağlanması, rol-yapma etkinlikleri gibi konuşma becerisini destekleyen yöntem ve tekniklerin kullanılması ile ders kitabı dışında konuşma ve dinleme becerisini geliştirmeye yönelik kullanılan materyallerin çeşitlendirilmesi önerilmektedir. $\mathrm{Bu}$ anlamda programa beceri odaklı (skill-based) bir yapının kazandırılması avantaj ve dezavantajlar göz önünde bulundurularak değerlendirilmeli, tam olarak beceri odaklı bir yapı sağlanmasa bile konuşma ve dinleme dersi adı altında ayrı bir dersin programa eklenmesi tavsiye edilmektedir. Kur sisteminin okulun fiziki yapısı, olanakları ve öğrenciler açısından olumsuz etkileri ve faydaları göz önünde bulundurularak uygulanabilirliğinin değerlendirilmesi fayda sağlayabilir. Bunun yanında öğretim elemanları, okul yönetimi ve program geliştirme uzmanlarının iş birliğiyle bilimsel veriler ışığında öncelikli olarak bir ihtiyaç analizi ve sonrasında hedeflerin ayrıntılı olarak belirtildiği resmi bir öğretim programının geliştirilmesi çalışmalarının yapılması araştırmacılar tarafından özellikle önerilmektedir.

Ayrıca, bu konuda yürütülmesi planlanan bundan sonraki araştırmalar için de bazı öneriler getirilebilir. Necmettin Erbakan Üniversitesi Yabancı Diller Yüksekokulu tarafından yayımlanmış resmi bir öğretim programı bulunmadığından bundan sonra yürütülecek araştırmalarda ihtiyaç analizi ve program geliştirme çalışmaları yürütülebilir. Ayrıca Yabancı Diller Yüksekokulu tarafından resmi olarak uygulanan yazılı bir öğretim programının bulunmaması nedeniyle bu araştırmada öğrencilerin bir yıllık zorunlu hazırlık eğitiminin İngilizce başarıları üzerindeki etkisi ve öğrencilerin program ile ilgili algıları incelenerek hazırlık programının etkililiği değerlendirilmeye çalışılmıştır. $\mathrm{Bu}$ nedenle resmi öğretim programı yayımlandıktan sonra yürütülecek değerlendirme araştırmalarında mevcut öğretim programının unsurlarının ayrı ayrı ele alınarak değerlendirmenin yapılması önerilmektedir. 


\section{Summary}

Purpose and Significance: The importance of English in the international context has been emphasized in various studies (British Council \& TEPAV, 2014; British Council \& TEPAV, 2015; Kırkgöz, 2007; Koru ve Åkesson, 2011). These ongoing problems in the field of foreign language teaching has been mentioned frequently in the literature (British Council \& TEPAV, 2014; Koru \& Åkesson, 2011; Yücel vd., 2017). Also, it has been indicated in the literature that there are similar problems exist in language teaching area in higher education institutions in Turkey (British Council \& TEPAV, 2015; Coşkun, 2013; Gömleksiz, 2002; Toker, 1999). Preparatory schools providing high quality language education play a critical role in promoting English language education in higher education institutions in Turkey as mentioned by Toker (1999). In a similar vein, it can be said that preparatory school education is essential in compensating students' English deficiency. Necmettin Erbakan University offers foreign language courses in the Fall and Spring semesters in a variety of departments at the faculties, high schools and vocational schools and preparatory programs both in English and German. The English preparatory program organized by School of Foreign Languages is a yearlong English teaching program offered for students who plan to study in one of the departments at Necmettin Erbakan University. No studies were identified in the literature that investigated the effectiveness of compulsory English preparatory program at Necmettin Erbakan University School of Foreign Languages which is of vital importance for the students who are about to start higher education. Furthermore, when the relevant literature was examined, it was noted that most of the studies that investigated the effectiveness of preparatory programs at different universities (Coşkun, 2013; Gerede, 2005; Özkanal \& Hakan, 2010; Toker, 1999) focused on student and lecturer views. This study differed from the previous studies in that attention was paid to student success as well as student views on the program. So, the purpose of this study was to investigate the effectiveness of compulsory English preparatory program at Necmettin Erbakan University School of Foreign Languages. Considering the above purpose, this study sought answer to the following question: What are students' perceptions of the effectiveness of English compulsory preparatory program? Additionally, a hypothesis was proposed as follows: English compulsory preparatory program improves students' English proficiency.

Methods: Explanatory mixed-method research design was employed in which both quantitative and qualitative approaches were used. In the quantitative part of the study, the proficiency test administered at the beginning of the academic year was used as the post-test to assess the students' progress in English. A total of 70 students participated in the quantitative phase of the study. Afterwards, semi-structured, face-to-face interviews were conducted with 20 compulsory preparatory class students (10 female and 10 male) in the qualitative phase to follow up and refine the quantitative findings. The proficiency test was prepared by the exam board constituted by the directorship of School of Foreign Languages. The test originally comprised of listening, reading, language use, vocabulary and writing parts. In the study, the writing part was excluded from test as it could affect the reliability and validity in a negative way because of the difficulty of evaluating it objectively. Accordingly, the total test scores administered at the beginning of the academic year was calculated by excluding the writing part and 
used as the pre-test results. Also, a semi-structured interview form was designed by the researchers following a review of literature in accordance with the purpose of the study and was piloted with 3 compulsory preparatory class students. The interview form included seven open-ended questions aimed at determining student views of the compulsory English preparatory program. Data collection took place in the spring semester of the academic year 2016-2017. Participants were given 60 minutes to complete the proficiency test and the interviews lasted 10-18 minutes each. Students were informed that participation in the study was voluntary at the beginning of the study. The proficiency test results were analyzed by dependent samples t test in SPSS 16.0 for Windows statistical package. Also, the qualitative data was analyzed by content analysis, which includes a four-step process: coding, conceptualizing, categorizing and explanation (Yıldırım \& Şimşek, 2008, s. 228).

Results: There was a statistically significant difference between pre-test and post test scores, indicating an improvement in the proficiency level of the participants. The results of the qualitative data analysis supported the quantitative findings. It was found that students entered the program mostly because they wanted to learn English at a satisfactory level, their departments required them to complete the preparatory program successfully and they wanted to speak English fluently. Also, most of the students reported that they were satisfied with the program while some of them reported partial satisfaction because of the deficiencies in developing especially speaking and listening skills. Considering the effect of the program on English proficiency, students reported that the program had a positive effect mostly on writing and reading skills, whereas it had a relatively less positive effect on listening and speaking skills. Regarding the students' suggestions and criticism with respect to the program, it was found that although student views were varied, it could be said they were generally on the idea that more emphasis must be placed on speaking skill instead of excessive stress on grammar.

Discussion and Conclusions: The qualitative and quantitative results of the study show that English preparatory program at Necmettin Erbakan University School of Foreign Languages improved students' proficiency level and students had generally positive opinions about preparatory program though some deficiencies were noted especially in developing listening and speaking skills. It is believed that students' general satisfaction with the program is a positive indicator of their progress in English, which also shows the effectiveness of the program. However, it is worthy of note that some deficiencies were also indicated by some students and these issues about the courses, lecturers and evaluation are of great importance which need to be addressed carefully in order to improve the quality of the program. It is believed that one of the most significant results of the study is the students' opinion that grammar is overemphasized while speaking skill is neglected in some way, which could be resulted from foreign language learning environment, lack of necessary materials and use of unfavorable language teaching methods and techniques teachers may use. It may be remarked that developing an authorized curriculum by indicating general and specific objectives in detail, implementing it with a central focus on student needs and improving it by consistent evaluation can compensate these deficiencies indicated by the students. 


\section{Kaynakça}

Arap, B. (2016). Türkiye'de üniversite düzeyindeki Ingilizce hazırlık programlarının uygulanmasına dair bir inceleme (Yayımlanmamış doktora tezi). Çukurova Üniversitesi, Adana.

British Council, \& TEPAV (2014). Türkiye'deki devlet okullarında İngilizce dilinin öğretimine ilişkin ulusal ihtiyaç analizi. 16.02.2018 tarihinde http://www.tepav.org.tr/upload/files/1399388519-

1.Turkiyedeki_Devlet_Okullarinda_Ingilizce_Dilinin_Ogrenimine_Iliskin_Ulusal_ Ihtiyac_Analizi.pdf adresinden erişilmiştir.

British Council, \& TEPAV (2015). Türkiye'de yükseköğretim kurumlarındaki İngilizce eğitimi. 21.02.2018 tarihinde https://www.britishcouncil.org.tr/sites/default/files/20160211_english_he_baseline_ study_final_tr.pdf adresinden erişilmiştir.

Celce-Murcia, M. (Ed.). (2001). Teaching English as a second or foreign language ( $3^{\text {rd }}$ ed.). Boston, MA: Heinle and Heinle Publishers.

Coşkun, A. (2013). An investigation of the effectiveness of the modular general English language teaching preparatory program at a Turkish university. South African Journal of Education, 33(3), 1-18. 26.02.2018 tarihinde http://www.sajournalofeducation.co.za/index.php/saje/article/view/809/368 adresinden erşilmiştir.

Davras, G. M., \& Bulgan, G. (2012). Meslek yüksekokulu (MYO) öğrencilerinin İngilizce hazırlık eğitimine yönelik tutumları: Isparta MYO Turizm ve Otel İşletmeciliği örneği. Doğuş Üniversitesi Dergisi, 13(2), 227-238. 20.03.2018 tarihinde http://journal.dogus.edu.tr/index.php/duj/article/view/572 adresinden erişilmiştir.

Fraenkel, J. R., Wallen, N. E., \& Hyun, H. H. (2012). How to design and evaluate research in education ( $8^{\text {th }}$ ed.). New York: McGraw-Hill.

Gerede, D. (2005). A curriculum evaluation through needs analysis: Perceptions of intensive English program graduates at Anadolu University (Yayımlanmamış yüksek lisans tezi). Anadolu Üniversitesi, Eskişehir.

Gömleksiz, M. N. (2002). Üniversitelerde yürütülen yabancı dil derslerine ilişkin öğrenci görüşlerinin değerlendirilmesi (Frrat Üniversitesi Örneği). Fırat Üniversitesi Sosyal Bilimler Dergisi, 12(1), 143-158. 15.03.2018 tarihinde http://web.firat.edu.tr/sosyalbil/dergi/arsiv/cilt12/sayi1/143-158.pdf adresinden erişilmiştir.

Grabe, W., \& Stoller, F. L. (2001). Reading for academic purposes: Guidelines fort he ESL/EFL teacher. In M. Celce-Murcia (Ed.), Teaching English as a second or foreign language (pp. 187-203). Boston, MA: Heinle and Heinle Publishers.

Kaçar, I. G., \& Zengin, B. (2009). İngilizceyi yabancı dil olarak öğrenenlerin dil öğrenme ile ilgili inançları, öğrenme yöntemleri, dil öğrenme amaçları ve öncelikleri arasındaki ilişki: Öğrenci boyutu. Journal of Language and Linguistic Studies, $\quad 5(1), \quad 55-89 . \quad 20.03 .2018 \quad$ tarihinde http://www.jlls.org/index.php/jlls/article/view/73 adresinden erişilmiştir. 
Kırkgöz, Y. (2007). English language teaching in Turkey: Policy changes and their implementations. Regional Language Centre Journal, 38(2), 216-228. http://dx.doi.org/10.1177/0033688207079696

Kirkgöz, Y. (2009). Students' and lecturers' perceptions of the effectiveness of foreign language instruction in an English-medium university in Turkey. Teaching in Higher Education, 14(1), 81-93. https://doi.org/10.1080/13562510802602640

Koru, S., \& Åkesson, J. (2011). Turkey’s English deficit (Policy note). Economic Policy Research Foundation of Turkey (TEPAV). 01.03.2018 tarihinde http://www.tepav.org.tr/upload/files/1324458212-1.Turkey_s_English_Deficit.pdf adresinden erişilmiştir.

Lazaraton, A. (2001). Teaching oral skills. In M. Celce-Murcia (Ed.), Teaching English as a second or foreign language (pp. 103-115). Boston, MA: Heinle and Heinle Publishers.

MEB (2018a). Ilköğretim Ingilizce Dersi (İlkokul ve Ortaokul 2, 3, 4, 5, 6, 7 ve 8. Sinıflar) Ögretim Programı. $16.02 .2018 \quad$ tarihinde http://mufredat.meb.gov.tr/ProgramDetay.aspx?PID=327 adresinden erişilmiştir.

MEB (2018b). Ortaöğretim Ingilizce Dersi (9, 10, 11, ve 12. Sinıflar) Öğretim Programi. 16.02.2018 tarihinde http://mufredat.meb.gov.tr/ProgramDetay.aspx?PID=342 adresinden erişilmiştir.

Mede, E., \& Uygun, S. (2014). Evaluation of a language preparatory program: A case study. ELT Research Journal, 3(4), 201-221. 13.03.2018 tarihinde http://dergipark.gov.tr/download/article-file/63648 adresinden erişilmiştir.

Miles, M. B., \& Huberman, A. M. (1994). Qualitative data analysis: An expanded sourcebook. Thousand Oaks, CA: Sage.

Necmettin Erbakan Üniversitesi Yabancı Diller Yüksekokulu Yabancı Dil Öğretimi ve Yabancı Dille Öğretim Yönetmeliği [YDÖY] (2012), T.C. Resmi Gazete, 28508, 25 Aralik 2012.

Necmettin Erbakan Üniversitesi Yabancı Diller Yüksekokulu Yabancı Dil Öğretimi ve Yabancı Dille Öğretim Yönetmeliği’nde Değişiklik Yapılmasına Dair Yönetmelik (2017), T.C. Resmi Gazete, 30246, 20 Kasim 2017.

Oxford, R. (2001). Integrated skills in the ESL/EFL classroom. ERIC Digest. 23.03.2018 tarihinde https://files.eric.ed.gov/fulltext/ED456670.pdf adresinden erişilmiştir.

Örs, M. (2006). An analysis of the preparatory students' attitudes toward the appropriateness of the preparatory school program at the university of Gaziantep (Yayımlanmamış yüksek lisans tezi). Gaziantep Üniversitesi, Gaziantep.

Özkanal, Ü., \& Hakan, A. G. (2010). Effectiveness of university English preparatory programs: Eskisehir Osmangazi University Foreign Languages Department English Preparatory Program. Journal of Language Teaching and Research, 1(3), 295-305. http://dx.doi.org/10.4304/jltr.1.3.295-305

Seven, M. A. (2004). Atatürk Üniversitesi Fen Bilimleri Enstitüsü hazırlı sınıflarında uygulanan dil öğretim programının amacına ulaşma düzeyi (Yayımlanmamış doktora tezi). Atatürk Üniversitesi, Erzurum. 
Şen Ersoy, N., \& Kürüm Yapıcıoğlu, D. (2015). İsteğe bağlı İngilizce hazırlık programının öğrenci ve okutman görüşlerine göre değerlendirilmesi. Eğitimde Nitel $\begin{array}{llll}\text { Araştırmalar } \quad \text { Dergisi, } & \text { 7-43), }\end{array}$ http://dx.doi.org/10.14689/issn.21482624.1.3c3s1m

Talim ve Terbiye Kurulu Başkanlığı (TTKB) (2013). 2013 Yll Kurul Kararları. 16.02.2018 tarihinde http://ttkb.meb.gov.tr/kurulkararlari/fihristler/fihrist_2013.pdf adresinden erişilmiştir.

Toker, O. (1999). The attituted of teaching staff and students towards the preparatory curriculum of the department of foreign languagesin the University of Gaziantep (Yayımlanmamış yüksek lisans tezi). Gaziantep Üniversitesi, Gaziantep.

Tunç, F. (2010). Evaluation of English language teaching program at a public university using CIPP Model (Yayımlanmamış yüksek lisans tezi). Orta Doğu Teknik Üniversitesi, Ankara.

Yıldırım, A., \& Şimşek, H. (2008). Sosyal bilimlerde nitel araştırma yöntemleri (6. Bask1). Ankara: Seçkin Yayıncılık.

Yücel, E., Dimici, K., Yıldız, B., \& Bümen, N. T. (2017). Son 15 yılda yayımlanan ilk ve ortaöğretim İngilizce dersi öğretim programları üzerine bir analiz. Ege Eğitim Dergisi, $\quad$ 18(2), 702-737. 16.02.2018 tarihinde http://dergipark.gov.tr/download/article-file/369885 adresinden erişilmiştir.

Yükseköğretim Kurulu Başkanlığı (YKB) (2016). Yükseköğretim Kurumlarında Yabancı Dil Öğretimi ve Yabancı Dille Öğretim Yapılmasında Uyulacak Esaslara İlişkin Yönetmelik. 15.03.2018 tarihinde http://www.yok.gov.tr/web/guest/mevzuat;jsessionid=96D6A84635A442D8EB18B 495A6175E7D adresinden erişilmiştir. 